\title{
RESPONSE GROWTH AND PRODUCTIVITY OF SNAP BEAN (PHASEOLUS VULGARIS L.) PLANTS TO ORGANIC MANURE FERTILIZATION, IRRIGATION REGIMES AND FOLIAR SPRAYING WITH ASCORBIC ACID UNDER NEWLY RECLAIMED SOIL CONDITION
}

\author{
R. H. M. Geeth and M. A. Abdel-Aziz \\ Self-Pollination Veget. Dept.; Hort. Res. Inst.; Agric., Res. Center, Giza, Egypt. \\ Corresponding author: E-mail:drmedhataziz@yahoo.com
}

Received: Jun. 11, 2017

Accepted: Jul. 5, 2017

\begin{abstract}
Two field experiments were carried out in private farm at Bani Mazar region, AlMinia Governorate, Egypt, during the two fall seasons of 2015 and 2016 under drip irrigation system, in sandy soil. The objectives of this experiment were to study the effect of three factors i.e. cattle manure fertilization at three rates $\left(20,30\right.$ and $40 \mathrm{~m}^{3} / \mathrm{fed}$.), water regimes at three levels (100, 80 or $60 \%)$ from snap bean plant irrigation requirements /fed. and foliar spray with ascorbic acid at two concentrations (100 and $200 \mathrm{mg} / \mathrm{L}$ ) beside the control and their interactions on growth, productivity, water use efficiency ( $\mathrm{Kg}$ yield $\mathrm{m}^{3}$ water) as well as some chemical composition in leaves and green pods of snap bean plants. The experimental design was split-split-plot, the treatments were designated in sub-sub-plot i.e. cattle manure rates in the main plots, water regimes in the sub plots, while foliar spray with ascorbic acid arranged in the sub-sub-plot. Seeds of snap bean Bronco cv. were sown in the $2^{\text {nd }}$ week of September during the two seasons.
\end{abstract}

The obtained results of the single treatments showed that, adding the degradation of cattle manure at rate of $30 \mathrm{~m}^{3} / \mathrm{fed}$. followed with rate of 40 then $20 \mathrm{~m}^{3} /$ fed., irrigated snap bean plants with $100 \%$ from snap bean plants irrigation requirements /fed. compared with $80 \%$ to $60 \%$ /fed. as well as foliar spraying with the aqueous solution of ascorbic acid especially at the highest rate of $200 \mathrm{mg} / \mathrm{L}$ as compared with the moderate rate one $(100 \mathrm{mg} / \mathrm{L})$ or the control treatment, markedly increased all studied parameters of vegetative growth organs, pods characters, total pod yield and its components. Moreover, the same mentioned single treatments showed obvious increment of the chemical composition in the leaves and the green pods. The lowest value of the fiber contents (\%) in the pods was obtained by adding the middle amount of cattle manure, full irrigation and the highest rate of ascorbic acid $(200 \mathrm{mg} / \mathrm{L})$. The highest water use efficiency was obtained by adding the middle amount of cattle manure, irrigation with $60 \%$ from snap bean plants irrigation requirements /fed. and the highest rate of foliar spraying with ascorbic acid, followed with $80 \%$ and 100 /fed. Increasing water deficient from $80 \%$ to $60 \%$ /fed. significantly decreasing all the measurements, increasing the nonmarketable yield (ton/fed.) and fiber contents \% in pods. Also, proline content $\%$ in snap bean leaves achieved increases up to irrigated plants with the middle water regime treatment only followed with $100 \%$ (control) but the highest severe water stress $(60 \% /$ /fed.) tended to decrease proline content $\%$.

Concerning to the results of the interactions among the three factors used in this study, it can be said that, the treatments led to significant increases in most of the studied characters, the best interaction treatment which led to obtain the highest means values over all the other treatments was adding cattle manure at $30 \mathrm{~m}^{3} / \mathrm{fed}$., irrigation schedule regime at $80 \%$ from snap bean plants irrigation requirements/ fed. and foliar spraying with ascorbic acid at the highest rate of $200 \mathrm{mg} / \mathrm{L}$ which increased the vegetative growth, marketable, total yield (ton/ fed.) and its components. In spite of increasing water use efficiency to the highest level with the interaction 
among cattle manure at $30 \mathrm{~m}^{3} / \mathrm{fed}$., irrigation regime at $60 \% / \mathrm{fed}$. and foliar spraying with ascorbic acid at the highest rate of $200 \mathrm{mg} / \mathrm{L}$. In addition, on the previous interaction was the favorite interaction to gain the highest marketable, total and the lowest weight of nonmarketable yield as well as it is can save $20 \%$ from irrigation requirements of snap bean plants/ fed. grown under the newly reclaimed of sandy loam soil conditions, also, increasing nutritive values i.e. carbohydrates, protein and decreasing the fiber contents \% in the pods as compared with the other rest interactions. On the contrary, the interaction of adding the cattle manure at $20 \mathrm{~m}^{3}$ /fed. with irrigation regime at $60 \%$ /fed. and foliar spraying with ascorbic acid at rate of $100 \mathrm{mg} / \mathrm{L}$ produced the lowest characters, these findings were true in the both fall seasons.

Key words: Snap bean, Cattle manure, Ascorbic acid, Irrigation regimes, Water use efficiency, Interaction and Newly reclaimed soil

\section{INTRODUCTION}

Snap bean (Phaseolus vulgaris L.) is a member of fabaceae family, it is consider one of the most important vegetable crops in Egypt for local market and it has a great importance for exportation. Common bean is consider a major vegetable crop as a rich source of protein and carbohydrates, as well as being a good source of vitamin $B$ complex such as niacin, riboflavin, folic acid and thiamine. It is, a source of mineral nutrients i.e. iron, copper, zinc, phosphorus, potassium, magnesium and calcium; furthermore, it is also, an excellent source of polyunsaturated fatty acids. Regular consumption of common bean reduces cholesterol levels in the blood. Common bean has great economic importance, as it generates income for small farmers (RochaGuzman and Gallegos-Infante, 2007).

Cattle manure application as organic fertilizer, may help alleviate soil erosion, decrease injury of saline and sodium problems which is increase in sandy soil as a result of an excessive residual of chemical fertilization and underground water. The use of the alternatives cow manure can provide a method to dispose of waste materials in an environmentally beneficial manner (Allahyari et al., 2008). Organic matter increase the pore space in the soil, where water can be held more easily, making the soil capable of storing more water during a longer period which makes the soil less dense, less compacted and become better physical properties for storing water or more withholding water capacity. As a consequence, a soil rich in organic matter needs less water for crop growing than the poor soil in organic matter. Application of the cattle manure to farmland is an economical and environmentally sustainable mechanism for increasing crop production. Organic matter retains plant nutrients and prevents them from leaching to deeper soil layers, enhancing soil structure, hold water in the soil and make nutrients more accessible to the plant (Lal, 2008).

Furthermore, application of solid cattle manure, moves soil $\mathrm{pH}$ towards neutrality. The $\mathrm{pH}$ also, plays an important role in the solubility of nutrients in the soil, thus improving nutrient availability especially for $P$ and micronutrients, to become more favorable for plant growth and beneficial microbial processes (Benke et al., 2008). Organic fertilization is an important role on produced higher number of pods/ plant, number of grains per pod, thousand grain weights and seed yield of bean plants as mentioned by Lunazendejas et al. (2011). Bakayoko et al. (2013) elucidate that adding the cattle manure at rate of 10 (ton/ ha.) significantly increased soil organic matter, improving the structural stability and increasing the water retention of the sandy soil. Chaudhury (2014) verified that soil organic matter helps to maintain good aggregation and increase water holding capacity and exchangeable $\mathrm{K}, \mathrm{Ca}$ and $\mathrm{Mg}$. It also, reduces $P$ fixation, leaching of 
nutrients and decreases toxicities of $\mathrm{Al}$ and $\mathrm{Mn}$.

As for, the water regimes, currently, the world is facing many problems of crop production as a result of water deficiency. Among of them, water deficit which is the most dangerous factor. Irrigation water is one of the most important factors for increasing agricultural production. Water is a very limited resource and most of Egypt's water uses are for the agriculture sector, which consumes about $84 \%$. Problems of water scarcity may increase because of population increment, of the rise in living standards and accelerated urbanization which threaten the water supply sector in general and agriculture in particular and lead to both an increase in water consumption. The demand for irrigation water will continue to increase because of higher domestic and industrial water consumption by the year 2030 may cause a decrease in the volume of fresh water available for agriculture (AbuZeid and Hamdy, 2002).

One of the most common irrigation methods in Egypt is furrow irrigation, resulting in high water losses and low irrigation efficiencies especially for using under the old Delta conditions (clay soil). Drip irrigation have been considered to be one of the most important obligatory irrigation systems and increase water consumption efficiency, which has to be applied in the newly reclaimed desert areas as well as old Delta soils, for saving much irrigation water especially for using it under the old Delta conditions instead the traditional surface irrigation system, which could be used to reclaim and cultivate more desert land areas or to avoid the shortage of water resources in Egypt. Efficient use of water in any irrigation system is becoming important particularly in arid and semiarid region where water is a scarce commodity. There are specific problems in the management of sandy soils including their excessive permeability, low water and nutrient holding capacities. Drip irrigation systems exhibited the highest values of snap bean vegetative growth, pods yield (kg/ fed.) and water used efficiency, meanwhile furrow irrigation recorded the lowest values in the same concern (El-Noemani et al., 2010).

Moreover, water is the most important factor in determining the growth and development of snap bean (Phaseolus vulgaris L.). Drought contributes is one of the most factor to reduce the number of flowers, pod setting and poor quality of pods resulting in low yield. In this respect, exposure to drought stress causes morphological, physiological, biochemical and molecular changes that negatively affect plant growth and yield. The ability to uptake and allocate nutrients is a key factor in plant tolerance to drought. Common bean is sensitive to drought stress, which can cause yield losses of more than $50 \%$ (Razinger et al., 2010). Increases in reactive oxygen species production in drought-stressed, such as superoxide anion $\left(\mathrm{O}_{2}^{-}\right)$, hydrogen peroxide $\left(\mathrm{H}_{2} \mathrm{O}_{2}\right)$ and hydroxyl radical $\left(\mathrm{OH}^{-}\right)$ are damageable for cellular structures and macromolecules, associated disturbances in carbohydrate metabolism causing photo inhibition of the photosynthetic apparatus. In addition, it can directly damage membrane lipids, inactivate metabolic enzymes and damage nucleic acids, leading to cell death. Water deficit leads to oxidative stress in plant cells, due to a higher leakage of electrons toward $\mathrm{O}_{2}$, during the photosynthetic and respiratory processes, leading to enhancement in reactive oxygen species (Sánchez-Rodríguez et al., 2012). El-Tohamy et al. (2013) indicated that water stress levels resulted in a significant decline of leaf water potential, stomatal conductance, photosynthesis rate and all growth, productivity and quality parameters of bean plants. Finding relatively safe tools and treatments to overcome the negative effects of drought stress or improve drought tolerance of sensitive plants could be of great value especially under arid and semiarid conditions as shortage of water 
becomes a limiting factor for growth and productivity in such conditions.

As respect of, foliar spraying ascorbic acid as an antioxidant treatment, Smirnof and Wheeler (2000) postulated that ascorbic acid as an abundant component of plants functions as an antioxidant and an enzyme cofactor. It participates in essential factors of processes, including photosynthesis, cell wall growth and cell expansion, resistance to environmental stresses and synthesis of ethylene, gibberellins, anthocyanine and hydroxyl proline. Conklin (2001) suggested that ascorbic acid is an important antioxidant, which reacts not only with $\mathrm{H}_{2} \mathrm{O}_{2}$ but also, with $\mathrm{O}_{2}, \mathrm{OH}$ and lipid hydroperoxidases, which cause reactive oxygen species (ROS) are responsible for various stress-induced damages to macromolecules and ultimately to cellular structure. El-Shiekh et al. (2016) declared that foliar application of ascorbic acid at rate of $g / 10 \mathrm{~L}$ increase in the growth and development of faba bean plants might be due to enhancement of cell division, cell enlargement and influence DNA replication.

The main objectives of this study were to investigate the effect of the appropriate amount of adding the cattle manure, exact irrigation regime and the best dose of foliar spraying with ascorbic acid to enhance growth, pod characters, yield productivity, water use efficiency and some chemical properties, in order to be saving $20 \%$ from irrigation requirements of snap bean plants/ fed. grown under the newly reclaimed of sandy loam soil conditions without any reduction on pod yield and its quality.

\section{MATERIALS AND METHODS}

Two field experiments were initiated during the two fall seasons of 2015 and 2016 in sandy soil in private farm at Bani Mazar region, North Al-Minia Governorate, Egypt. Coordinates: its located $28.50^{\circ}$ North latitude and $30.80^{\circ}$ East longitude and it is situated at elevation 43 meters above sea level. The objectives of this study were to determine the exact amount of the cattle manure, water regimes and the best rate of foliar application of ascorbic acid as well as their interactions under the condition of the newly reclaimed soil on growth, yield and its components, water use efficiency as well as some chemical constituents of leaves and pods of (Phaseolus vulgaris L.) Bronco cv. Soil samples were randomly collected each year before cultivation at a depth of $0-30 \mathrm{~cm}$ in order to measure contents of the physical and chemical properties which determined according to (Jackson, 1973) were shown in Table (1).

The experimental design was split-splitplot; the treatments were arranged in a complete randomized block design with three replicates. The main plots were devoted for the three amounts of the degradation cattle manure (factor A) with rates of 20,30 and $40 \mathrm{~m}^{3} /$ feddan. which were added at the time of soil preparation, trenched in the bottom of the rows with the basic fertilizers which as phosphorus fertilizer in the form of calcium super phosphate $\left(15.5 \% \mathrm{P}_{2} \mathrm{O}_{5}\right)$ at rate of 200 $\mathrm{kg} / \mathrm{fed}$., ammonium sulfate $20.6 \% \mathrm{~N}$, at rate of $150 \mathrm{~kg} / \mathrm{fed}$., potassium sulfate $\left(50 \% \mathrm{~K}_{2} \mathrm{O}\right)$ at rate of $50 \mathrm{~kg} / \mathrm{fed}$. and agriculture sulpher at rate of $50 \mathrm{~kg} / \mathrm{fed}$. covered by $20 \mathrm{~cm}$ height of sand (Amer et al., 2012). The other agricultural practices such as irrigation system, weed control, insects and diseases control were used according to the recommendations of Egyptian Ministry of Agriculture under the conditions of this region. The physical and chemical analyses of organic manure are shown in the Table (2). Drip irrigation system was used (including GR, with discharge rate of $4 \mathrm{~L} / \mathrm{h}$ was spaced at $25 \mathrm{~cm}$ intervals) to apply the three levels of water schedule regimes (factor B) as sub plots treatments, i.e. $100 \%$ (full irrigation) with $2320 \mathrm{~m}^{3}, 80 \%$ (moderate stress) with $1856 \mathrm{~m}^{3}$ and $60 \%$ (severe stress) with $1392 \mathrm{~m}^{3}$ water/ feddan, respectively from irrigation requirements of snap bean plants. 
Table (1): Physical and chemical analysis properties of the experiment soil.

\begin{tabular}{|c|c|c|}
\hline Components & $1^{\text {st }}$ season & $2^{\text {nd }}$ season \\
\hline Soil Type & sand loam & sand loam \\
\hline Organic Matter \% & 0.33 & 3.45 \\
\hline Clay \% & 4.59 & 26.08 \\
\hline Silt \% & 24.66 & 37.75 \\
\hline Fine Sand \% & 42.24 & 32.22 \\
\hline Coarse Sand \% & 28.51 & 7.82 \\
\hline pH & 7.72 & 0.79 \\
\hline E.C. $(\mathrm{mmhos} / \mathrm{cm})$ & 0.70 & 8.13 \\
\hline CaCO3 \% & 8.39 & 0.027 \\
\hline Total N $\%$ ) & 0.033 & 39.00 \\
\hline Available $\mathrm{P} \mathrm{mg} / 100 \mathrm{~g}$ & 38.79 & 377.9 \\
\hline Available $\mathrm{K} \mathrm{mg} / 100 \mathrm{~g}$ & 369.6 & \\
\hline
\end{tabular}

Table (2): Physical and chemical analysis of the degradation cattle manure used in this experiment.

\begin{tabular}{|c|c|c|}
\hline Components & $1^{\text {st }}$ season & $2^{\text {nd }}$ season \\
\hline Total nitrogen \% & 0.42 & 0.48 \\
\hline Total phosphorus \% & 0.32 & 0.31 \\
\hline Total potassium \% & 1.02 & 1.13 \\
\hline Organic Matter & 44.60 & 41.19 \\
\hline Organic Carbon & 23.15 & 25.72 \\
\hline C:N Ratio & $26.3: 1$ & $23.2: 1$ \\
\hline pH & 7.82 & 7.99 \\
\hline E. C. $($ ds. $\mathrm{m} / \mathrm{L})$ & 4.76 & 5.33 \\
\hline
\end{tabular}

Total water irrigation $\left(\mathrm{m}^{3} /\right.$ fed.) was estimated according to the meteorological data of the Central Laboratory for Agricultural Climate, Agricultural Research Center, Ministry of Agriculture, Giza, Egypt under the condition at Bani Mazar region. All experimental units were received equal amounts of water until the complete germination (from 15 days after seed sowing date) then irrigation treatments were started in the both seasons. Foliar application of ascorbic acid $^{\circledR}$ (factor C) was located randomly distributed in the sub-sub- plots. Plants were sprayed with ascorbic acid at rate of 0,100 and $200 \mathrm{mg} / \mathrm{L}$ at three times i.e. 25,35 and 45 days after sowing date.

Seeds of snap bean Bronco cv. were purchased from Horticulture Research 
Institute, Agricultural Research Center and sown in the $2^{\text {nd }}$ week on September of 2015 and 2016, respectively in the both seasons. The area of experimental plot was $11.2 \mathrm{~m}^{2}$. Each plot consisted of 4 rows dripper lines at $4 \mathrm{~m}$ in length and $0.7 \mathrm{~m}$ in width, seeds were sown with two seeds/ hill at $5-7 \mathrm{~cm}$ apart on one side of dripper lines. At 15 days after sowing, plants were thinned leaving one plant/ hill.

\section{The following parameters were recorded:}

1- Growth parameters: five plants from each treatment were randomly chosen at 60 days after sowing date (at the beginning of bud setting stage) to measure i.e. plant height, number of branches and dry weight of foliage/ plant (leaves and stems).

2-1-Green pods yield and its components: At harvest time pods were harvested and samples were taken from each treatment at the $2^{\text {nd }}$ picking, as a random samples of 20 fresh pods from five plants, to determine the following data i.e. average of each: pod length $(\mathrm{cm})$, pod diameter $(\mathrm{cm})$, pod weight $(\mathrm{g})$ and number of pods/ plant. All pickings at suitable maturity stage were calculated as non-marketable, marketable and total pods yield in (ton/ fed.).

2-2-Non-marketable yield: Includes the defective, malformed, pale coloured, broken, overgrown, short and small pods, with symptoms of pest and diseases damage.

2-3-Marketable yield: Includes the pods which are characterized to be shiny green, intact, straight, with a fresh appearance and without any defects pest, diseases and not deformed.

2-4-Total yield: Includes all the harvested pods.

2-5-Water Use Efficiency (WUE): Water use efficiency $\left(\mathrm{Kg}\right.$ yield $/ \mathrm{m}^{3}$ water $)$ is an indicator of the efficiency of irrigation in increasing snap bean crop yield. It was calculated from the following equation: Water use efficiency is typically defined as the crop yield ( $\mathrm{Kg}$ yield/ fed.) divided by the amount of water used ( $\mathrm{m}^{3}$ water/ fed.) for each treatment (Rahil and Qanadillo, 2015).

WUE $=$

Total pods yield $\left(\mathrm{Kg} / \mathrm{fed}\right.$.) $=\mathrm{Kg} / \mathrm{m}^{3}$

Total applied of irrigation water $\left(\mathrm{m}^{3} / \mathrm{fed}\right.$.)

\section{3-Chemical composition in leaves and green pods:}

Fresh weight of samples from snap bean leaves and pods were dried in an electric forced-air oven at $70^{\circ} \mathrm{C}$ to constant weight, then fractionated and sifting. The fine powder (at $0.2 \mathrm{~g}$ ) of each dry sample was digested in a mixture of sulphuric acid and hydrogen peroxide according to Thomas (1967) to determine:

3-1-Total nitrogen content (\%) in dry leaves by using the modified "Micro-Kjeldahl" method apparatus of Parnas and Wagner as described by Pregl (1945).

3-2-Protein (\%) was determined in dry pods through the determination of pod total $\mathrm{N}$ and a factor of 6.25 was used for conversion of total $\mathrm{N}$ to protein percentage according to Kelly and Bliss (1975).

3-3-Phosphorus content (\%) was estimated spectrophotometrically in dry leaves using the chloraostannous reduced molybdophosphoric blue color method in sulphuric acid system as described by King (1951).

3-4-Potassium content (\%) was determined in dry leaves using the Flamephotometr as described by Brown and Jackson (1955).

3-5-Total chlorophyll content $(\mathrm{mg} / 100 \mathrm{~g}$ fresh weight) was determined at 60 days after sowing date in the fresh leaves (random sample of five fresh leaves from the plants top/ plot), according to Nagata and Yamashita (1992). 
3-6-Total carbohydrates content (\%) in dry pods was determined according to Dubois et al. (1975).

3-7-The fibers content (\%) in dry pods was determined according to Rai and Mudgal (1988).

3-8-The free proline content (\%) in dry leaves was determined using acidic ninhydrin according to using spectrophotometer according to the method described by Troll and Lindsley (1955).

\section{4-Statistical analysis:}

All data of the present study was subjected to the analysis of variance techniques according to the design used by the MSTATC computer software program variance and mean of treatments were compared according to the Least Significant Differences (L. S. D.) test at the 0.05 probability level, method described by (Bricker, 1991).

\section{RESULTS AND DISCUSSION I- Vegetative growth parameters:- 1-1-Effect of adding the cattle manure:}

The data recorded in Table (3) show that, using cattle manure at the moderate amount (30 $\mathrm{m}^{3} / \mathrm{fed}$.) markedly increased the vegetative growth characters i.e. plant height, number of branches and dry weight/ plant of snap bean plants comparing to the lowest or the highest amounts (20 or 40 $\mathrm{m}^{3} / \mathrm{fed}$.), these findings were true in the both fall seasons. The pronounce effects of the cattle manure may be due to its contain many species of living organisms which release phytohormones like, gibberellic acid, indole acetic acid and cytokinins which stimulates plant growth, absorption of nutrients and photosynthesis processes as menationed by (Reyndres and Vlassake, 1982). The richness in organic matter improves soil physical characteristics, increased structural stability, better porosity, higher water retention capabilities and the activity of micro-organisms, which makes the soil less dense, less compacted and with gives it better physical properties for high avilable water, more drought resistant, increasing the water use efficiency and retains plant nutrients and prevents them from leaching to deeper soil layers. Then crops fertilized with organic mater have been shown to more successfully resist drought, torrential rains as well as economical and environmentally sustainable mechanism for increasing crop production (Abiven et al., 2008). The favorable increases in the vegetative growth characters of the snap bean plants under using the cattle manure treatments, are attributable to created good conditions for increasing the water holding capacity and accordingly the role of organic matter in the release of the nutrients, notably nitrogen (as mention before in Table 2, of physical and chemical analysis of the cattle manure) which is an essential element for building protoplasm, amino acids and proteins which induced cell division and initiate meristematic activity. Also, nitrogen was a constituent of chlorophyll molecule, elongation, growth, development of plant, phosphorous and potassium are essential nutrients playing an important role in the biosynthesis and translocation of carbohydrates and necessary for stimulating cell division.

Concerning the less values of growth characters which obtained with adding the highest amount of the cattle manure (40 $\mathrm{m}^{3} / \mathrm{fed}$.) comparing with adding the moderate amount $\left(30 \mathrm{~m}^{3} / \mathrm{fed}\right.$.), this may be returned to the retain an excess with water, in this case, the soil is compaction and poorly aerated as well as the soil microbes quickly consume all the oxygen dissolved in the soil water for respiration, will switch to anaerobic respiration and use alternatives to oxygen $\left(\mathrm{O}_{2}\right)$ to breathe. Some of these alternatives to $\mathrm{O}_{2}$ include plant available nitrate $\left(\mathrm{NO}_{3}{ }^{-}\right)$and sulphate $\left(\mathrm{SO}_{4}{ }^{2-}\right)$ that are converted to gases and lost to the atmosphere (Benke et al., 2008). 
Table (3): Effect of adding the cattle manure, irrigation schedule regimes, foliar application of ascorbic acid and their interactions on plant height, number of branches and dry weight/ plant of snap bean plants during the two fall seasons of 2015 and 2016

\begin{tabular}{|c|c|c|c|c|c|c|c|c|}
\hline \multirow{2}{*}{$\begin{array}{l}\text { Cattle manure } \\
\text { amounts } \\
\left(\mathrm{m}^{3} / \mathrm{fed} .\right)\end{array}$} & \multirow{2}{*}{$\begin{array}{l}\text { Irrigation } \\
\text { schedule } \\
\text { regimes (\%) }\end{array}$} & \multirow{2}{*}{$\begin{array}{l}\text { Foliar application } \\
\text { of ascorbic acid } \\
(\mathrm{mg} / \mathrm{L})\end{array}$} & \multicolumn{2}{|c|}{ Plant height $(\mathrm{cm})$} & \multicolumn{2}{|c|}{\begin{tabular}{|c|} 
Number of \\
branches/ plant
\end{tabular}} & \multicolumn{2}{|c|}{$\begin{array}{l}\text { Dry weight }(\mathrm{g}) / \\
\text { plant }\end{array}$} \\
\hline & & & \begin{tabular}{|c|}
$1^{\text {st }}$ \\
season \\
\end{tabular} & $\begin{array}{c}2^{\text {nd }} \\
\text { season } \\
\end{array}$ & \begin{tabular}{|c|}
$1^{\text {st }}$ \\
season \\
\end{tabular} & \begin{tabular}{|c|}
$2^{\text {nd }}$ \\
season \\
\end{tabular} & $\begin{array}{c}1^{\text {st }} \\
\text { season } \\
\end{array}$ & $\begin{array}{c}2^{\text {nd }} \\
\text { season } \\
\end{array}$ \\
\hline \multirow{9}{*}{20 ( $\mathrm{m}^{3} /$ fed. $)$} & \multirow{3}{*}{$100 \%$} & Control & 34.7 & 35.5 & 4.7 & 4.6 & 4.937 & 5.143 \\
\hline & & $100 \mathrm{mg} / \mathrm{L}$ & 37.8 & 38.1 & 4.8 & 4.7 & 4.993 & 5.190 \\
\hline & & $200 \mathrm{mg} / \mathrm{L}$ & 40.7 & 41.3 & 4.9 & 4.8 & 5.080 & 5.287 \\
\hline & \multirow{3}{*}{$80 \%$} & Control & 33.3 & 33.8 & 4.6 & 4.5 & 4.783 & 4.957 \\
\hline & & $100 \mathrm{mg} / \mathrm{L}$ & 39.7 & 38.5 & 4.8 & 4.7 & 5.430 & 5.237 \\
\hline & & $200 \mathrm{mg} / \mathrm{L}$ & 44.0 & 44.9 & 5.0 & 5.1 & 5.347 & 5.543 \\
\hline & \multirow{3}{*}{$60 \%$} & Control & 33.0 & 33.2 & 4.3 & 4.3 & 4.450 & 4.657 \\
\hline & & $100 \mathrm{mg} / \mathrm{L}$ & 38.1 & 38.8 & 4.5 & 4.4 & 4.743 & 4.953 \\
\hline & & $200 \mathrm{mg} / \mathrm{L}$ & 39.1 & 40.3 & 4.7 & 4.6 & 4.953 & 5.170 \\
\hline \multicolumn{3}{|c|}{ Mean for $A$} & 37.8 & 38.3 & 4.7 & 4.7 & 4.968 & 5.126 \\
\hline \multirow{9}{*}{$30\left(\mathrm{~m}^{3} /\right.$ fed. $)$} & \multirow{3}{*}{$100 \%$} & Control & 42.2 & 41.1 & 5.9 & 6.0 & 7.947 & 8.097 \\
\hline & & $100 \mathrm{mg} / \mathrm{L}$ & 42.9 & 42.1 & 6.1 & 6.1 & 8.173 & 8.260 \\
\hline & & $200 \mathrm{mg} / \mathrm{L}$ & 43.4 & 44.9 & 6.2 & 6.3 & 8.357 & 8.570 \\
\hline & \multirow{3}{*}{$80 \%$} & Control & 39.5 & 38.4 & 5.7 & 5.8 & 6.477 & 6.673 \\
\hline & & $100 \mathrm{mg} / \mathrm{L}$ & 46.3 & 45.8 & 6.7 & 6.6 & 8.837 & 8.997 \\
\hline & & $200 \mathrm{mg} / \mathrm{L}$ & 48.0 & 48.9 & 6.8 & 6.9 & 9.410 & 9.780 \\
\hline & \multirow{3}{*}{$60 \%$} & Control & 38.3 & 37.3 & 5.6 & 5.5 & 5.817 & 5.990 \\
\hline & & $100 \mathrm{mg} / \mathrm{L}$ & 40.5 & 39.5 & 5.7 & 5.6 & 7.227 & 7.413 \\
\hline & & $200 \mathrm{mg} / \mathrm{L}$ & 42.6 & 41.3 & 6.1 & 5.9 & 7.383 & 7.623 \\
\hline \multicolumn{3}{|c|}{ Mean for $A$} & 42.6 & 42.1 & 6.0 & 6.1 & 7.736 & 7.934 \\
\hline \multirow{9}{*}{$40\left(\mathrm{~m}^{3} / \mathrm{fed}.\right)$} & \multirow{3}{*}{$100 \%$} & Control & 37.2 & 39.2 & 4.6 & 4.7 & 4.920 & 5.007 \\
\hline & & $100 \mathrm{mg} / \mathrm{L}$ & 41.3 & 42.0 & 4.7 & 4.8 & 5.073 & 5.257 \\
\hline & & $200 \mathrm{mg} / \mathrm{L}$ & 42.1 & 43.7 & 5.0 & 4.9 & 5.013 & 5.420 \\
\hline & \multirow{3}{*}{$80 \%$} & Control & 37.1 & 38.0 & 4.7 & 4.6 & 4.780 & 4.657 \\
\hline & & $100 \mathrm{mg} / \mathrm{L}$ & 39.9 & 42.3 & 5.1 & 5.0 & 5.387 & 5.590 \\
\hline & & $200 \mathrm{mg} / \mathrm{L}$ & 43.3 & 44.1 & 5.5 & 5.3 & 5.810 & 5.990 \\
\hline & \multirow{3}{*}{$60 \%$} & Control & 35.0 & 35.1 & 4.6 & 4.4 & 4.817 & 5.097 \\
\hline & & $100 \mathrm{mg} / \mathrm{L}$ & 38.4 & 39.7 & 4.7 & 4.6 & 5.010 & 5.210 \\
\hline & & $200 \mathrm{mg} / \mathrm{L}$ & 39.0 & 40.1 & 5.0 & 5.2 & 5.223 & 5.400 \\
\hline \multicolumn{3}{|c|}{ Mean for $\mathrm{A}$} & 39.3 & 40.5 & 4.8 & 4.8 & 5.115 & 5.292 \\
\hline \multirow{3}{*}{\multicolumn{2}{|c|}{ Mean for B }} & $100 \%$ & 40.3 & 40.9 & 5.2 & 5.2 & 6.050 & 6.248 \\
\hline & & $80 \%$ & 41.2 & 41.6 & 5.4 & 5.4 & 6.251 & 6.380 \\
\hline & & $60 \%$ & 38.2 & 38.6 & 5.0 & 5.0 & 5.514 & 5.724 \\
\hline & & Control & 36.7 & 37.8 & 4.9 & 4.9 & 5.436 & 5.586 \\
\hline Mean & for $C$ & $100 \mathrm{mg} / \mathrm{L}$ & 40.5 & 40.8 & 5.2 & 5.2 & 6.108 & 6.234 \\
\hline & & $200 \mathrm{mg} / \mathrm{L}$ & 42.5 & 43.3 & 5.4 & 5.5 & 6.286 & 6.531 \\
\hline LSD at 5 & for A (Cattle & anure $\mathrm{m}^{3} /$ fed.) & 2.1 & 2.4 & 0.17 & 0.24 & 0.29 & 0.33 \\
\hline L S D at $5 \% \mathrm{fc}$ & r B (Irrigation s & hedule regimes \%) & N.S. & N.S. & 0.14 & 0.15 & N.S. & N.S. \\
\hline S D at $5 \%$ for & (Foliar applic & ion of ascorbic acid) & 1.3 & 1.5 & 0.13 & 0.17 & 0.18 & 0.11 \\
\hline LSD & at $5 \%$ for inte & ction $A^{*} B$ & 1.7 & 1.9 & 0.16 & 0.17 & 0.24 & 0.14 \\
\hline LSD & at $5 \%$ for inte & ction $A^{*} C$ & 1.6 & 1.8 & 0.14 & 0.18 & 0.20 & 0.12 \\
\hline LSD & at $5 \%$ for inte & ction $\mathrm{B}^{\star} \mathrm{C}$ & 1.6 & 1.8 & 0.14 & 0.18 & 0.20 & 0.12 \\
\hline LSD & $5 \%$ for inter & tion $A^{*} B^{\star} C$ & 2.3 & 2.4 & 0.12 & 0.21 & 0.29 & 0.18 \\
\hline
\end{tabular}


As the results of the lowest growth characters obtained with adding the lowest amount of the cattle manure $\left(20 \mathrm{~m}^{3} / \mathrm{fed}\right.$.) comparing with adding the moderate amount (30 $\mathrm{m}^{3} / \mathrm{fed}$.), this may be due to limited amount of the cattle manure per feddan which didn't make the soil capable of storing or saving more water, more dense, also, its can't retain nutrients and not prevent them from leaching to deeper soil layers and less drought resistant during the longer period, especially under the newly reclaimed of sandy soil (as the condition of this investigation). The obtained results are in a good accordance with those recorded by Karangwa et al. (2015) investigated the adding of the cow dung at amount of 20 ton/ ha. they obtained significant increases in plants height, stem girth and number of leaves of bean plants at three, five, seven and nine weeks after plantation.

\section{1-2-Effect of water regimes:}

The data registered in Table (3) exhibited also that there were significant differences in the vegetative growth characters of snap bean plants under the three irrigation schedule regimes treatments. The maximum vegetative growth characters were recorded with using the full irrigation (100\% of plants irrigation requirements /fed.) followed by the moderate irrigation stress regime (80\% /fed.) then the severe water stress regime (60\%/ fed.). Decrement in all studied growth aspects significantly gained with increasing water stress levels from $80 \%$ to $60 \%$ /fed. The largest reduction in growth characters of snap bean plants were observed under severe water stress (60\%/fed.) during the two seasons of this study, that is may be attributed to the main role of water in increasing the absorption of macro and micro nutrients from the soil and in turn affect plant vegetative growth, water is consider the main constituents in photosynthetic process which consequently affect on the amounts of photosynthetic assimilates required for cells and tissues formation and in turn affect all morphological parameters of growing plants. In this respect, Abdul-Jaleel et al. (2009) mentioned that water stress inhibits cell enlargement more than cell division might be due either to decreases in cell elongation resulting from the inhibiting effect of water shortage on growth-promoting hormones which, in turn, lead to decreases in cell turgor and eventually growth. Water-stress conditions cause a marked suppression in plant photosynthetic efficiency, mainly due to the closing of stomata and inhibition of (Rubisco) enzyme. El-Noemani, et al. (2010) recorded that the reduction in number of branches of snap bean plants owing to the low soil moisture level may be due to the reduction in the uptake of nutritional elements that caused deterrence in the physiological processes needed for plant growth. The increase in dry matter of plants grown in high levels of soil moisture could be attributed mainly to the effect of water on some quantitative, qualitative changes in certain metabolic processes, enhancing cell division and enlargement which need more water supplies. Findings are also, in conformity with many researchers for other legumes like, Neama et al. (2016) concluded that snap bean plants receiving $100 \%$ of the potential evapotranspiration reached to the highest plant height, leaf number and branch number per plant. Significant reduction in the vegetative growth characters were obtained with the treatment of $80 \%$ followed by $60 \%$. The lowest vegetative growth was obtained by $60 \%$ during the both seasons.

\section{1-3-Effect of foliar spraying with ascorbic acid:}

Results in Table (3) sharply clear that the foliar application of ascorbic acid treatments created significant ascending effects on growth parameters of snap bean plants i.e. plant highest, number of branches and dry weight of foliage/ plant. Ascorbic acid was the most effective treatment at the highest dose $(200 \mathrm{mg} / \mathrm{L})$ as compared with the moderate one $(100 \mathrm{mg} / \mathrm{L})$ and the control (zero $\mathrm{mg} / \mathrm{L}$ ) treatments, the previous 
characters are true during the both fall seasons. These findings are in accordance with Hosny et al. (2015) assumed that the highest values of plant height, number of leaves per plant as well as fresh and dry weights of shoots on snap bean plants were recorded as a result of spraying plants with $400 \mathrm{mg} / \mathrm{L}$ of ascorbic acid compared with the control.

\section{1-4-Effect of the interactions:}

Significant interactions effects were found among of all three studied factors, (Table 3). The tallest plants with more branches and the heaviest dry weight of snap bean plants were obtained with adding the cattle manure at $30 \mathrm{~m}^{3} /$ fed. with the moderate irrigation regime i.e., $80 \%$ from plant irrigation requirements /fed. and foliar spray with ascorbic acid especially at the highest rate of $200 \mathrm{mg} / \mathrm{L}$. On the contrary, the lowest records of the previous character obtained with the interaction among of adding the cattle manure at the amount of $20 \mathrm{~m}^{3} /$ fed., water deficient at $60 \% / \mathrm{fed}$. of water regime and foliar spraying with ascorbic acid at $100 \mathrm{mg} / \mathrm{L}$ as compared with the rest of the other interactions treatment. These results reinforced with, Amira (2014) who, decided that the interaction effects induced significant increases of all growth features of soybean plants with an increasing effect at $80 \%$ and $60 \%$ field capacity with foliar application of ascorbic acid at 100 and $200 \mathrm{mg} / \mathrm{L}$. Hosny et al. (2015) proposed that the highest values of all measured growth parameters were recorded as a result of the interactions between irrigation of snap bean plants with $100 \%$ of pan evapotranspiration and spraying with the highest concentration of ascorbic acid at the dose of $400 \mathrm{mg} / \mathrm{L}$.

\section{2-Yield and its components: 2-1-Effect of cattle manure:}

The data in Tables (4 and 5) indicate that, snap bean plants which received cattle manure at the amount of $30 \mathrm{~m}^{3} /$ fed. in the both seasons, gained the best pods characters i.e. pod length, pod diameter, pod weight, number pods/ plant, the highest values of marketable, total yield, water use efficiency ( $\mathrm{Kg}$ yield $/ \mathrm{m}^{3}$ water) as well as the lowest values of non-marketable pod yield (ton/fed.) as compared with the two other amounts of the cattle manure 20 or $40 \mathrm{~m}^{3}$ / fed. On the contrast, the worst records of pod characters, the highest non-marketable, the lowest marketable, total yield (ton/fed.) and water use efficiency were obtained with adding the lowest amount of cattle manure (20 $\mathrm{m}^{3} /$ fed.) followed by adding the highest amount i.e., $40 \mathrm{~m}^{3} /$ fed. The increases in the yield and its components as a result of adding the ideal amount of the cattle manure was attributed to the role of organic matter in supplied the plants with nutrient-sufficient, which increases the vegetative organs and thus reflect on the photosynthesis process, which increase cells activity, size, increase the components of yield such as pod number per plant, seeds number per pod and seed yield on garden bean plants (Kovacs et al., 2008). The obtained results are in accordance with those of Karangwa et al. (2015) they noticed that adding cow dung with a dose of 20 ton/ ha. lead to obtained significant increases in number of bean pods and yield.

\section{2-2-Effect of water regimes:}

Data recorded in the same Tables illustrate that the effect of water irrigation regimes i.e. $100 \%, 80 \%$ and $60 \%$ from plant irrigation requirements/ fed. on yield and its components measurements as well as water use efficiency reveale that, snap bean plants irrigated with the complete irrigation treatment (100\%/ fed.) lead to the maximum increases on yield and its components as well as the lowest values of non-marketable yield followed with those plant irrigated with $80 \%$ then $60 \% /$ fed. Irrigated plants with $60 \% / f e d$. increased water use efficiency followed with the plants irrigated with $80 \%$ and $100 \% /$ fed (unstressed plants). On the contrary, the lowest results of pod characters, marketable, total and the highest weight of 
the non-marketable yield (ton/fed.) were significantly obtained when the plants were irrigated with the lowest water amount i.e. 60 $\% /$ fed. compared with the plants irrigated with the other levels, during the two fall seasons. The reduction in the yield and its components as a result of increment the water stress levels may be due to the negative effect of water stress on the growth characters, pod weight and number of pods which contribute to the final total yield, as discussed before (see Tables 3 and 4). In this orientation, Abdul-Jaleel et al. (2009) indicated that water deficit is one of the major a biotic stress, which adversely affects of plant growth and yield. These changes are mainly related to the alteration of metabolic functions, conditions due to increasing the rate of flower abscission such as the reduction in the synthesis of photosynthesis pigments, thereby these changes in the amount of photosynthetic pigments are closely associated to plant biomass yield. Yield may be reduced under drought and pod abortion of soybean (Liu et al., 2003). The previous findings coincided with those obtained by Hosny et al. (2015), they commented that different water stress levels $(50$ and $35 \%$ of pan evapotranspiration) were significantly decreased number and weight of pods/ plant, pod length, pod diameter and the total yield/ fed. comparing with full irrigation level (100\%) of snap bean plants. Neama et al. (2016) regarded that snap bean plants receiving $100 \%$ of the potential evapotranspiration produced the highest number of pods, fresh pods weight/ plant and the total pod yield (ton/ ha.). Plants receiving $60 \%$ produced the highest reduction in the previous characters and the highest value of the water use efficiency.

\section{2-3-Effect of foliar spraying with ascorbic acid:}

It is discernible from the data in Tables (4 and 5) that, the most pronounced effects on pod characters, marketable, total yield, water use efficiency as well as the lowest weight of the non-marketable yield (ton/fed.) of snap bean plants, were achieved by the foliar application of ascorbic acid at the highest rate of $200 \mathrm{mg} / \mathrm{L}$ compared with the moderate level of $100 \mathrm{mg} / \mathrm{L}$ or the control treatment. This positive effect of ascorbic acid on yield, its components and water use efficiency may be attributed to its role as a cofactor for enzymes involved in photosynthesis, hormone biosynthesis and the regeneration of antioxidants (Gallie, 2012). Hosny et al. (2015) proved that spraying snap bean plants with ascorbic acid at rate of $400 \mathrm{mg} / \mathrm{L}$ increased number, weight of pods, pod length, pod diameter per plant and total yield/ fed. when compared with the control treatment.

\section{2-4-Effect of the interactions:}

With regard to the effect of all interactions among the three factors on yield, its components and water use efficiency the results in Tables (4 and 5) showed that, adding cattle manure at the amount of $30 \mathrm{~m}^{3} /$ fed. with irrigation schedule regime $(80 \%)$ from plant irrigation requirements/fed. and foliar spraying with ascorbic acid at the highest rate of $200 \mathrm{mg} /$ $\mathrm{L}$, was the best interaction treatments which produced the highest values over the other two interactions treatments, it is gave the best pod characters and the highest values of marketable pods (4.237 and 4.359 ton/fed.), total pods yield (4.453 and 4.594 ton/fed.) and the lowest weight of nonmarketable pod yield $(0.216$ and 0.235 ton/fed.) in the $1^{\text {st }}$ and the $2^{\text {nd }}$ season, respectively. The best water use efficiency $\left(2.951\right.$ and $2.958 \mathrm{Kg}$ yield $/ \mathrm{m}^{3}$ water) occurred with adding cattle manure at the amount of $30 \mathrm{~m}^{3} /$ fed. with irrigation schedule regime (60 \%) from plant irrigation requirements /fed. and foliar spraying with ascorbic acid at the highest rate of $200 \mathrm{mg} / \mathrm{L}$. On the contrast, the lowest records on yield and its components was obtained with the interactions treatment among of the cattle manure at the amount of $20 \mathrm{~m}^{3} /$ fed., water deficient at $60 \% /$ fed. and foliar spraying with ascorbic acid at $100 \mathrm{mg} / \mathrm{L}$. There were non-significant increases with the moderate irrigation stress regime ( $80 \% /$ fed.) in the pod diameter, pod weight, number of pods/ plant, non- marketable yield (ton/ fed.) and in the pod diameter with foliar spraying of ascorbic acid treatments in the two seasons. 
Table (4): Effect of adding the cattle manure, irrigation schedule regimes, foliar application of ascorbic acid and their interactions on pod length, pod diameter, pod weight and number of pods/ snap bean plants during the two fall seasons of 2015 and 2016

\begin{tabular}{|c|c|c|c|c|c|c|c|c|c|c|}
\hline \multirow{2}{*}{$\begin{array}{c}\text { Cattle manure } \\
\text { amounts } \\
\left(\mathrm{m}^{3} / \mathrm{fed} .\right)\end{array}$} & \multirow{2}{*}{$\begin{array}{l}\text { Irrigation } \\
\text { schedule } \\
\text { regimes (\%) }\end{array}$} & \multirow{2}{*}{\begin{tabular}{|c} 
Foliar \\
application of \\
ascorbic acid \\
(mg/L)
\end{tabular}} & \multicolumn{2}{|c|}{$\begin{array}{l}\text { Pod length } \\
\text { (cm) }\end{array}$} & \multicolumn{2}{|c|}{$\begin{array}{c}\text { Pod diameter } \\
(\mathrm{cm})\end{array}$} & \multicolumn{2}{|c|}{$\begin{array}{l}\text { Pod weight } \\
\text { (g) }\end{array}$} & \multicolumn{2}{|c|}{$\begin{array}{l}\text { No. of pods / } \\
\text { plant }\end{array}$} \\
\hline & & & $\begin{array}{c}1^{\text {st }} \\
\text { season } \\
\end{array}$ & \begin{tabular}{|c|}
$2^{\text {nd }}$ \\
season
\end{tabular} & $\begin{array}{c}1^{\text {st }} \\
\text { season }\end{array}$ & \begin{tabular}{|c|}
$2^{\text {nd }}$ \\
season
\end{tabular} & $\begin{array}{c}1^{\text {st }} \\
\text { season }\end{array}$ & \begin{tabular}{|c|}
$2^{\text {nd }}$ \\
season
\end{tabular} & $\begin{array}{c}1^{\text {st }} \\
\text { season }\end{array}$ & $\begin{array}{c}2^{\text {nd }} \\
\text { season }\end{array}$ \\
\hline \multirow{9}{*}{$20\left(\mathrm{~m}^{3} /\right.$ fed. $)$} & \multirow{3}{*}{$100 \%$} & Control & 11.2 & \begin{tabular}{|l|}
11.3 \\
\end{tabular} & 0.52 & 0.53 & 5.100 & 5.033 & 24.0 & 24.6 \\
\hline & & $100 \mathrm{mg} / \mathrm{L}$ & 11.3 & 11.5 & 0.54 & 0.53 & 5.183 & 5.113 & 25.0 & 25.3 \\
\hline & & $200 \mathrm{mg} / \mathrm{L}$ & 11.7 & 11.6 & 0.54 & 0.55 & 5.323 & 5.250 & 25.2 & 26.4 \\
\hline & \multirow{3}{*}{$80 \%$} & Control & 11.0 & 10.9 & 0.51 & 0.50 & 5.037 & 4.933 & 23.4 & 23.7 \\
\hline & & $100 \mathrm{mg} / \mathrm{L}$ & 12.1 & 11.7 & 0.55 & 0.55 & 5.300 & \begin{tabular}{|l|}
5.187 \\
\end{tabular} & 26.6 & 25.5 \\
\hline & & $200 \mathrm{mg} / \mathrm{L}$ & 12.2 & 12.3 & 0.58 & 0.58 & 5.397 & \begin{tabular}{|l|}
5.440 \\
\end{tabular} & 25.7 & 26.9 \\
\hline & \multirow{3}{*}{$60 \%$} & Control & 10.8 & 10.9 & 0.48 & 0.46 & 4.773 & 4.867 & 20.2 & 20.7 \\
\hline & & $100 \mathrm{mg} / \mathrm{L}$ & 11.0 & 11.1 & 0.48 & 0.49 & 4.900 & 4.913 & 21.2 & 20.9 \\
\hline & & $200 \mathrm{mg} / \mathrm{L}$ & 11.3 & 11.4 & 0.51 & 0.51 & 5.003 & 5.087 & 22.8 & 22.9 \\
\hline \multicolumn{3}{|c|}{ Mean of $A$} & 11.4 & 11.4 & 0.52 & 0.52 & 5.113 & 5.091 & 24.0 & 24.2 \\
\hline \multirow{9}{*}{30 ( $\mathrm{m}^{3} /$ fed.) } & \multirow{3}{*}{$100 \%$} & Control & 12.2 & 12.5 & 0.57 & 0.58 & 7.153 & \begin{tabular}{|l|}
7.167 \\
\end{tabular} & 27.5 & 28.0 \\
\hline & & $100 \mathrm{mg} / \mathrm{L}$ & 12.6 & 12.7 & 0.58 & 0.59 & 7.243 & 7.240 & 27.7 & 28.6 \\
\hline & & $200 \mathrm{mg} / \mathrm{L}$ & 12.7 & 12.9 & 0.59 & 0.59 & 7.410 & 7.343 & 29.1 & 29.3 \\
\hline & \multirow{3}{*}{$80 \%$} & Control & 12.0 & 12.2 & 0.55 & 0.55 & 7.077 & 6.980 & 26.2 & 27.0 \\
\hline & & $100 \mathrm{mg} / \mathrm{L}$ & 13.1 & 13.4 & 0.60 & 0.61 & 7.370 & 7.467 & 28.8 & 29.6 \\
\hline & & 200 & 13.8 & 13.6 & 0.62 & 0.62 & 7.670 & 7.890 & 30.5 & 30.8 \\
\hline & \multirow{3}{*}{$60 \%$} & Control & 11.8 & 11.9 & 0.52 & 0.52 & 6.877 & 6.773 & 25.4 & 25.3 \\
\hline & & $100 \mathrm{mg} / \mathrm{L}$ & 12.0 & 12.1 & 0.54 & 0.55 & 6.990 & \begin{tabular}{|l|}
6.877 \\
\end{tabular} & 26.8 & 26.9 \\
\hline & & $200 \mathrm{mg} / \mathrm{L}$ & 12.5 & 12.3 & 0.56 & 0.57 & 6.920 & 7.070 & 28.0 & 28.3 \\
\hline \multicolumn{3}{|c|}{ Mean of $A$} & 12.5 & 12.6 & 0.57 & 0.58 & 7.190 & 7.201 & 27.8 & 28.2 \\
\hline \multirow{9}{*}{$40\left(\mathrm{~m}^{3} /\right.$ fed. $)$} & \multirow{3}{*}{$100 \%$} & Control & 11.7 & 11.8 & 0.53 & 0.54 & 6.200 & 6.090 & 26.7 & 26.9 \\
\hline & & $100 \mathrm{mg} / \mathrm{L}$ & 12.2 & 12.3 & 0.55 & 0.55 & 6.270 & 6.113 & 27.2 & 27.7 \\
\hline & & $200 \mathrm{mg} / \mathrm{L}$ & 12.4 & 12.5 & 0.56 & 0.57 & 6.393 & 6.350 & 28.7 & 28.1 \\
\hline & \multirow{3}{*}{$80 \%$} & Control & 11.4 & 11.5 & 0.51 & 0.52 & 6.087 & 6.003 & 26.1 & 25.6 \\
\hline & & $100 \mathrm{mg} / \mathrm{L}$ & 12.5 & 12.7 & 0.58 & 0.58 & 6.477 & 6.510 & 27.9 & 28.3 \\
\hline & & $200 \mathrm{mg} / \mathrm{L}$ & 12.8 & 12.9 & 0.60 & 0.58 & 6.700 & 6.813 & 28.9 & 29.7 \\
\hline & \multirow{3}{*}{$60 \%$} & Control & 11.3 & 11.4 & 0.49 & 0.50 & 5.883 & 5.870 & 24.3 & 24.3 \\
\hline & & $100 \mathrm{mg} / \mathrm{L}$ & 11.5 & 11.7 & 0.50 & 0.51 & 5.900 & \begin{tabular}{|l|}
5.987 \\
\end{tabular} & 25.5 & 25.8 \\
\hline & & $200 \mathrm{mg} / \mathrm{L}$ & 11.8 & 11.9 & 0.53 & 0.56 & 6.007 & 6.123 & 26.7 & 26.9 \\
\hline & Mean of $A$ & & 12.0 & 12.1 & 0.54 & 0.55 & 6.213 & 6.207 & 26.9 & 27.0 \\
\hline & & $100 \%$ & 12.0 & 12.1 & 0.55 & 0.56 & 6.253 & \begin{tabular}{|l|}
6.188 \\
\end{tabular} & 26.7 & 27.2 \\
\hline & $B$ & $80 \%$ & 12.3 & 12.4 & 0.57 & 0.58 & 6.346 & 6.358 & 27.0 & 27.6 \\
\hline & & $60 \%$ & 11.5 & 11.6 & 0.51 & 0.52 & 5.917 & 5.952 & 24.5 & 24.7 \\
\hline Man & for & Control & 11.5 & 11.6 & 0.52 & 0.52 & 6.021 & 5.968 & 24.9 & 25.1 \\
\hline Mie & for C & $100 \mathrm{mg} / \mathrm{L}$ & 12.0 & 12.1 & 0.54 & 0.55 & 6.182 & 6.160 & 26.2 & 26.6 \\
\hline & & $200 \mathrm{mg} / \mathrm{L}$ & 12.3 & 12.4 & 0.56 & 0.57 & 6.350 & 6.374 & 27.3 & 27.4 \\
\hline LSD at 5 & $\begin{array}{l}\text { for A (Cattle } \\
\text { fed.) }\end{array}$ & manure $\mathrm{m}^{3} /$ & 0.24 & 37 & 0.03 & 0.05 & \begin{tabular}{|l|l|}
0.243 \\
\end{tabular} & 0.353 & 0.81 & 0.95 \\
\hline LSD at $5^{\circ}$ & $\begin{array}{l}\text { for B (Irrigati } \\
\text { regimes \%) }\end{array}$ & on schedule & 0.15 & 0.24 & N.S. & N.S. & N.S. & N.S. & N.S. & N.S. \\
\hline $\begin{array}{r}\text { L SD at } 5 \% \\
a\end{array}$ & $\begin{array}{l}\text { for C (Foliar } \\
\text { scorbic acid }\end{array}$ & application of & 0.25 & 0.27 & N. S. & N. S. & 0.06 & 0.10 & 0.60 & 0.66 \\
\hline LSD at 5 & 6 for inter & ction $A^{*} B$ & 0.17 & 0.37 & 0.02 & 0.03 & 0.18 & 0.20 & 1.17 & 1.79 \\
\hline LSD & 6 for inter & ction $A^{*} \mathrm{C}$ & 0.27 & 0.30 & 0.02 & 0.02 & 0.07 & 0.17 & 0.67 & 0.74 \\
\hline LSD at 5 & $\%$ for intera & ction $B^{*} C$ & 0.27 & 0.30 & 0.02 & 0.02 & 0.07 & 0.17 & 0.67 & $\begin{array}{ll}0.74 \\
\end{array}$ \\
\hline LSD at 5 & for intera & tion $A^{*} B^{*} C$ & 0.40 & 0.43 & 0.04 & 0.05 & 0.10 & 0.18 & 0.97 & 1.06 \\
\hline
\end{tabular}


Table (5): Effect of adding the cattle manure, irrigation schedule regimes, foliar application of ascorbic acid and their interactions on non-marketable, marketable, total yield and water use efficiency of snap bean plants during the two fall seasons of 2015 and 2016

\begin{tabular}{|c|c|c|c|c|c|c|c|c|c|c|}
\hline \multirow{2}{*}{$\begin{array}{l}\text { Cattle manure } \\
\text { amounts } \\
\text { (m³/ fed.) }\end{array}$} & \multirow{2}{*}{$\begin{array}{l}\text { Irrigation } \\
\text { schedule } \\
\text { regimes (\%) }\end{array}$} & \multirow{2}{*}{$\begin{array}{c}\text { Foliar } \\
\text { application of } \\
\text { ascorbic acid } \\
(\mathrm{mg} / \mathrm{L})\end{array}$} & \multicolumn{2}{|c|}{$\begin{array}{c}\text { Non- } \\
\text { marketable } \\
\text { yield (Ton/ Fed.) }\end{array}$} & \multicolumn{2}{|c|}{$\begin{array}{c}\text { Marketable } \\
\text { yield } \\
\text { (Ton/ Fed.) }\end{array}$} & \multicolumn{2}{|c|}{$\begin{array}{l}\text { Total yield } \\
\text { (Ton/ Fed.) }\end{array}$} & \multicolumn{2}{|c|}{$\begin{array}{c}\text { Water use } \\
\text { efficiency } \\
\left(\mathrm{Kg} \text { yield } \mathrm{m}^{3}{ }_{\text {water }}\right)\end{array}$} \\
\hline & & & $\begin{array}{c}1^{1^{\text {st }}} \\
\text { season }\end{array}$ & $\begin{array}{c}2^{\text {nd }} \\
\text { season }\end{array}$ & $\begin{array}{c}1^{\text {st }} \\
\text { season }\end{array}$ & $\begin{array}{l}2^{\text {nd }} \\
\text { season }\end{array}$ & $\begin{array}{c}1^{\text {st }} \\
\text { eason }\end{array}$ & $\begin{array}{l}2^{\text {nd }} \\
\text { seaso }\end{array}$ & $\begin{array}{c}1^{\text {st }} \\
\text { season }\end{array}$ & \begin{tabular}{|c|}
$2^{\text {nd }}$ \\
season \\
\end{tabular} \\
\hline \multirow{9}{*}{20 ( $\mathrm{m}^{3} /$ fed. $)$} & \multirow{3}{*}{$100 \%$} & Control & 0.524 & 0.576 & 2.999 & 3.170 & 3.523 & 3.746 & 1.519 & 1.615 \\
\hline & & 100 & 0.497 & 0.540 & 3.037 & 3.258 & 3.534 & 3.798 & 1.523 & 1.637 \\
\hline & & 200 & 0.471 & 0.521 & 3.165 & 3.355 & 3.636 & 3.876 & 1.567 & 1.671 \\
\hline & \multirow{3}{*}{$80 \%$} & & 0.582 & 0.607 & 2.847 & 2.994 & 3.429 & 3.601 & 1.848 & 1.940 \\
\hline & & 100 & 0.451 & 0.496 & 3.372 & 3.292 & 3.823 & 3.788 & 2.060 & 2.041 \\
\hline & & 200 & 0.421 & 0.464 & 3.443 & 3.682 & 3.864 & 4.146 & 2.082 & 2.234 \\
\hline & \multirow{3}{*}{$60 \%$} & & 0.597 & 0.615 & 2.663 & 2.942 & 3.260 & 3.557 & 2.342 & 2.555 \\
\hline & & & 0.562 & 0.609 & 2.652 & 3.015 & 3.214 & 3.624 & 2.309 & 2.603 \\
\hline & & & 0.539 & 0.581 & 2.731 & 3.080 & 3.270 & 3.661 & 2.359 & 2.630 \\
\hline \multicolumn{3}{|c|}{ Mean of $A$} & 0.516 & 0.557 & 2.990 & 3.199 & 3.506 & 3.755 & 1.957 & 2.103 \\
\hline \multirow{9}{*}{30 ( $\left.\mathrm{m}^{3} / \mathrm{fed}.\right)$} & \multirow{3}{*}{$100 \%$} & ol & 0.263 & 0.297 & 3.802 & 3.873 & 4.065 & 4.170 & 1.752 & \begin{tabular}{|l|l|}
1.797 \\
\end{tabular} \\
\hline & & & 0.261 & 0.289 & 3.835 & 3.911 & 4.096 & 4.200 & 1.766 & 1.810 \\
\hline & & & 0.255 & 0.271 & 3.906 & 3.968 & 4.161 & 4.239 & 1.794 & \begin{tabular}{|l|l|}
1.827 \\
\end{tabular} \\
\hline & \multirow{3}{*}{$80 \%$} & & 0.297 & 0.331 & 3.661 & 3.721 & 3.958 & 4.052 & 2.183 & 2.231 \\
\hline & & & 0.233 & 0.250 & 4.029 & 4.279 & 4.262 & 4.529 & 2.296 & 2.440 \\
\hline & & & 0.216 & 0.235 & 4.237 & 4.359 & 4.453 & 4.594 & .399 & 2.475 \\
\hline & \multirow{3}{*}{$60 \%$} & & 0.351 & 0.346 & 3.536 & 3.611 & 3.887 & 3.957 & 792 & .843 \\
\hline & & & 0.341 & 0.338 & 3.571 & 3.646 & 3.912 & 3.984 & .810 & 2.862 \\
\hline & & & 0.328 & 0.329 & 3.780 & 3.789 & 4.108 & 4.118 & .951 & 2.958 \\
\hline \multicolumn{3}{|c|}{ of $A$} & 0.283 & 0.298 & 3.817 & 3.906 & & 4.205 & 2.305 & 2.360 \\
\hline \multirow{9}{*}{40 ( $\mathrm{m}^{3} /$ fed. $)$} & \multirow{3}{*}{$100 \%$} & & 0.481 & 0.495 & 3.576 & 3.541 & 4.057 & 4.036 & 1.749 & 1.740 \\
\hline & & 100 & 0.462 & 0.455 & 3.585 & 3.602 & 4.047 & 4.057 & 1.744 & 1.749 \\
\hline & & 200 & 0.451 & 0.450 & 3.651 & 3.660 & 4.102 & 4.110 & 1.768 & 1.772 \\
\hline & \multirow{3}{*}{$80 \%$} & in & 0.490 & 0.523 & 3.447 & 3.392 & 3.937 & 3.915 & 121 & 2.140 \\
\hline & & & 0.419 & 0.435 & 3.645 & 3.689 & 4.064 & 4.124 & 190 & 2.222 \\
\hline & & & 0.394 & 0.397 & 3.833 & 3.959 & \begin{tabular}{|l|}
4.224 \\
\end{tabular} & 4.356 & 2.276 & 2.347 \\
\hline & \multirow{3}{*}{$60 \%$} & & 0.489 & 0.544 & 2.910 & 3.298 & 3.399 & 3.842 & 2.042 & 2.451 \\
\hline & & $100 n$ & 0.456 & 0.508 & 3.048 & 3.400 & 3.504 & 3.908 & 2.517 & \begin{tabular}{|l|l|}
2.807 \\
\end{tabular} \\
\hline & & & 0.441 & 0.491 & 3.199 & 3.441 & 3.640 & 3.932 & 2.615 & 2.825 \\
\hline & Mean of $A$ & & 0.454 & 0.478 & 3.434 & 3.554 & 3.886 & 4.031 & .114 & \begin{tabular}{|l|}
2.228 \\
\end{tabular} \\
\hline & & & 0.407 & 0.435 & 3.506 & 3.593 & 3.913 & 4.025 & 1.687 & 1.735 \\
\hline Mea & & & 0.389 & 0.415 & 3.615 & 3.709 & 4.003 & 4.125 & 2.162 & 2.225 \\
\hline & & $\%$ & 0.456 & 0.485 & 3.121 & 3.358 & 3.577 & 3.843 & 2.526 & 2.726 \\
\hline & & Control & 0.453 & 0.482 & \begin{tabular}{|l|}
3.271 \\
\end{tabular} & 3.393 & 3.720 & 3.872 & 2.039 & \begin{tabular}{|l|}
2.146 \\
\end{tabular} \\
\hline Mea & & $100 \mathrm{mg} / \mathrm{L}$ & 0.409 & 0.435 & 3.419 & 3.566 & 3.829 & 4.002 & 2.135 & 2.241 \\
\hline & & 200 & 0.391 & 0.415 & 3.549 & 3.699 & 3.940 & 4.115 & 2.201 & 2.304 \\
\hline & $\Delta$ Cots & $n$ & 0.098 & 0.074 & 0.136 & 0.147 & 0.236 & 0.221 & .161 & 0.184 \\
\hline LSL & & edule regimes \%) & N. S. & N.S. & 0.064 & 0.059 & 0.079 & 0.084 & 116 & 0.145 \\
\hline LSDa & aiar & of ascorbic acid) & 0.025 & 0.023 & 0.060 & 0.052 & 0.097 & 0.128 & 0.109 & 0.135 \\
\hline $\mathrm{L}$ & $\%$ for interac & stion $A^{*} B$ & 0.041 & 0.051 & 0.122 & 0.143 & 0.197 & 0.166 & 0.111 & 0.158 \\
\hline & for inter & tion $A^{*} C$ & 0.027 & 0.026 & 0.172 & 0.159 & 0.183 & 0.174 & 0.145 & 0.167 \\
\hline & for & on $B^{*} \mathrm{C}$ & 0.027 & 0.026 & 0.172 & 0.159 & 0.183 & 0.174 & 0.145 & 0.167 \\
\hline LSD at & for intera & $A^{*} B^{*} C$ & 0.039 & 0.037 & 0.133 & 0.184 & 0.119 & 0.125 & 0.219 & 0.252 \\
\hline
\end{tabular}


Furthermore, the increases in the snap bean yield, its components and water use efficiency may be due to the role of ascorbic acid in counteracted the harmful effects of water stress especially with the highest dose of $200 \mathrm{mg} / \mathrm{L}$. In addition, increasing volume applied at $100 \%$ from plants irrigation requirements of plants means, decreasing in the concentration of nutrients in the root zone and also, applied $80 \% /$ fed. is the best case or suitable conditions, these conditions decreased from water stress or drought stress and also, achieved excellent distribution for nutrients inside root zone. While at $100 \%$ it can get the lowest water stress but not achieve excellent distribution for nutrients inside root zone because of increasing leaching rate with increasing volume of applied water. This increased in the pod yield can be explained by the significant increases due to the greatest values of the vegetative growth characters as well as the superior pod quality and number of pods/ plant as mention before in Tables 3 and 4 during the two growing seasons. These results are further supported by Amira (2014) who declared that, the interaction effects between water stress and foliar application of ascorbic acid at $200 \mathrm{mg} / \mathrm{L}$ tended to a reverse effect of water stress and increased the yield of soybean plants. In this respect, ascorbic acid counteracted the harmful effects of water stress on yield may be attributed to an increase in stomatal conductance and net photosynthetic $\mathrm{CO}_{2}$ fixation activity under water stress and also, to its role as an antioxidant, a cofactor for enzymes involved in photosynthesis and hormone biosynthesis (Gallie, 2012). Hosny et al. (2015) pointed out that there were significant interaction effects between water stress level at $50 \%$ of pan evapotranspiration and foliar spraying with ascorbic acid on snap bean plants at $400 \mathrm{mg} / \mathrm{L}$, which gave the highest length, diameter of pods, number and weight of pods/ fed.

\section{3-Chemical composition of snap bean leaves and pods: \\ 3-1-Effect of cattle manure:}

Effect of adding cattle manure at the three rates i.e. 20,30 and $40 \mathrm{~m}^{3} / \mathrm{fed}$. on the chemical composition of snap bean leaves and pods i.e. the total chlorophyll, proline, nitrogen, phosphorus and potassium content $\%$ in the leaves as well as the carbohydrates, fibers and protein $\%$ in the pods are presented in Tables 6 and 7 . The obtained data illustrate that adding the middle amount of cattle manure at $30 \mathrm{~m}^{3} /$ fed. induced significant increases in the total chlorophyll, carbohydrates, protein, nitrogen, phosphorus and potassium contents followed by adding 40 then $20 \mathrm{~m}^{3} /$ fed. of cattle manure treatments. The lowest values of the fiber \% in snap bean pods was obtained with adding $30 \mathrm{~m}^{3} /$ fed. as compared with the amount at $20 \mathrm{~m}^{3} /$ fed. which induced the highest percent of fibers in pods whereas, adding the cattle manure at $40 \mathrm{~m}^{3} /$ fed. ranked two. The highest content of proline \% in snap bean leaves significantly increased with adding the $2^{\text {nd }}$ amount of cattle manure followed with the $1^{\text {st }}$ and the $3^{\text {rd }}$ amounts. The obtained results are in accordance with those of Arjumand et al. (2013) they noticed that organic matter which contain most of the nutrients leads to increase the amount of protein and carbohydrates accumulated in the seeds which leads to increase the weight of the seeds of French bean plants. Bhaskarrao et al. (2015) assumed that the highest content of total chlorophyll, total sugars, soluble protein and amino acids were recorded in both of faba bean and pea plants grown in soil fertilized with cow dung (15 ton/ ha.) over the control treatment. 
Table (6): Effect of adding the cattle manure, irrigation schedule regimes, foliar application of ascorbic acid and their interactions on the total chlorophyll and proline content in leaves, carbohydrates and fibers content in pods of snap bean plants during the two fall seasons of 2015 and 2016

\begin{tabular}{|c|c|c|c|c|c|c|c|c|c|c|}
\hline \multirow{2}{*}{$\begin{array}{l}\text { Cattle manure } \\
\text { amounts } \\
\left(\mathrm{m}^{3} / \text { fed.) }\right.\end{array}$} & \multirow{2}{*}{\begin{tabular}{|c|} 
Irrigation \\
schedule \\
regimes (\%)
\end{tabular}} & \multirow{2}{*}{$\begin{array}{c}\text { Foliar } \\
\text { application of } \\
\text { ascorbic acid } \\
\text { (mg/L) }\end{array}$} & \multicolumn{2}{|c|}{$\begin{array}{c}\text { Total } \\
\text { chlorophyll } \\
\text { (mg/ } 100 \text { g F. W) }\end{array}$} & \multicolumn{2}{|c|}{$\begin{array}{c}\text { Carbohydrates } \\
\text { (\%) }\end{array}$} & \multicolumn{2}{|c|}{ Fibers (\%) } & \multicolumn{2}{|c|}{ Proline (\%) } \\
\hline & & & $1^{\mathrm{st}}$ & $2^{\text {nd }}$ & $1^{\mathrm{st}}$ & $2^{\text {nd }}$ & $1^{\mathrm{st}}$ & $2^{\text {nd }}$ & $1^{\text {st }}$ & $2^{\text {nd }}$ \\
\hline \multirow{9}{*}{$20\left(\mathrm{~m}^{3} / \mathrm{fed}.\right)$} & \multirow{3}{*}{$100 \%$} & Control & 106.90 & 112.12 & 13.46 & 13.85 & 11.54 & 11.33 & 0.263 & 0.257 \\
\hline & & $100 \mathrm{mg} / \mathrm{L}$ & 112.80 & 115.24 & 14.02 & 14.05 & 11.20 & 11.27 & 0.317 & 0.317 \\
\hline & & $200 \mathrm{mg} / \mathrm{L}$ & 117.83 & 122.11 & 14.71 & 14.47 & 11.00 & 11.19 & 0.337 & 0.333 \\
\hline & \multirow{3}{*}{$80 \%$} & Control & 101.43 & 107.12 & 13.29 & 13.55 & 11.67 & 11.75 & 0.283 & 0.267 \\
\hline & & $100 \mathrm{mg} / \mathrm{L}$ & 121.16 & 117.66 & 14.38 & 14.41 & 11.58 & 11.63 & 0.337 & 0.340 \\
\hline & & $200 \mathrm{mg} / \mathrm{L}$ & 125.00 & 128.43 & 14.38 & 14.43 & 11.13 & 11.54 & 0.350 & 0.350 \\
\hline & \multirow{3}{*}{$60 \%$} & ontrol & 96.82 & 100.51 & 12.61 & 13.01 & 11.82 & 11.82 & 0.257 & 0.240 \\
\hline & & $100 \mathrm{mg} / \mathrm{L}$ & 108.24 & 111.69 & 12.88 & 12.96 & 11.75 & 11.55 & 0.300 & 0.283 \\
\hline & & 200 & 115.83 & 119.80 & 13.38 & 13.37 & 11.31 & 11.33 & 0.303 & 0.307 \\
\hline \multicolumn{3}{|c|}{ Mean for $\mathrm{A}$} & 111.78 & 114.96 & 13.68 & 13.79 & 11.44 & 11.49 & 0.305 & 0.299 \\
\hline \multirow{9}{*}{$30\left(\mathrm{~m}^{3} / \mathrm{fed}.\right)$} & \multirow{3}{*}{$100 \%$} & Control & 138.83 & 144.46 & 16.12 & 16.20 & 9.45 & 9.64 & 0.307 & 0.310 \\
\hline & & $100 \mathrm{mg} / \mathrm{L}$ & 143.45 & 147.42 & 16.86 & 16.46 & 9.40 & 9.41 & 0.383 & 0.370 \\
\hline & & $200 \mathrm{mg} / \mathrm{L}$ & 153.89 & 148.75 & 17.16 & 16.65 & 9.21 & 9.26 & 0.393 & 0.380 \\
\hline & \multirow{3}{*}{$80 \%$} & Control & 128.16 & 131.70 & 15.98 & 15.77 & 9.48 & 9.76 & 0.353 & 0.377 \\
\hline & & $100 \mathrm{mg} / \mathrm{L}$ & 149.18 & 152.87 & 17.54 & 17.32 & 9.28 & 9.31 & 0.403 & 0.390 \\
\hline & & $200 \mathrm{mg} / \mathrm{L}$ & 157.72 & 159.02 & 18.40 & 17.65 & 9.08 & 9.24 & 0.430 & 0.437 \\
\hline & \multirow{3}{*}{$60 \%$} & Control & 123.45 & 118.56 & 15.63 & 15.41 & 9.50 & 9.83 & 0.287 & 0.283 \\
\hline & & $100 \mathrm{mg} / \mathrm{L}$ & 130.23 & 135.55 & 15.79 & 15.81 & 9.52 & 9.48 & 0.343 & 0.343 \\
\hline & & 200 & 144.50 & 139.43 & 16.40 & 16.51 & 9.32 & 9.35 & 0.357 & 0.360 \\
\hline \multicolumn{3}{|c|}{ Mean for $\mathrm{A}$} & 141.05 & 141.97 & 16.43 & 16.64 & 9.36 & 9.49 & 0.362 & 0.361 \\
\hline \multirow{9}{*}{$40\left(\mathrm{~m}^{3} / \mathrm{fed}.\right)$} & \multirow{3}{*}{$100 \%$} & Con & 112.72 & 119.86 & 15.11 & 15.14 & 11.04 & 11.07 & 0.220 & 0.210 \\
\hline & & $100 r$ & 116.44 & 121.49 & 15.17 & 15.01 & 11.02 & 11.06 & 0.250 & 0.260 \\
\hline & & $200 r$ & 120.79 & 126.93 & 15.95 & 15.80 & 10.88 & 10.84 & 0.270 & 0.280 \\
\hline & \multirow{3}{*}{$80 \%$} & $\overline{\text { on }}$ & 105.33 & 109.09 & 14.31 & 14.41 & 11.14 & 11.19 & 0.223 & 0.230 \\
\hline & & $\underline{L}$ & 124.77 & 129.35 & 15.64 & 15.52 & 10.93 & 10.93 & 0.270 & 0.280 \\
\hline & & 200 & 133.41 & 135.20 & 16.25 & 16.38 & 10.75 & 10.60 & 0.290 & 0.297 \\
\hline & \multirow{3}{*}{$60 \%$} & Control & 98.10 & 102.73 & 14.44 & 14.71 & 11.60 & 11.34 & 0.217 & 0.210 \\
\hline & & $100 \mathrm{mg} / \mathrm{L}$ & 111.78 & 108.81 & 14.90 & 14.84 & 11.23 & 11.09 & 0.240 & 0.253 \\
\hline & & $200 \mathrm{~m}$ & 119.06 & 114.63 & 15.13 & 15.46 & 11.05 & 10.88 & 0.257 & 0.267 \\
\hline & Mean for $\mathrm{A}$ & & 115.82 & 118.68 & 15.21 & 15.25 & 11.07 & 11.00 & 0.249 & 0.254 \\
\hline & & $100 \%$ & 124.85 & 128.74 & 15.29 & 15.35 & 10.53 & 10.57 & 0.303 & 0.301 \\
\hline Mear & for $B$ & $80 \%$ & 127.35 & 130.05 & 15.46 & 15.62 & 10.56 & 10.65 & 0.327 & 0.330 \\
\hline & & $60 \%$ & 116.45 & 116.86 & 14.57 & 14.71 & 10.79 & 10.74 & 0.284 & 0.283 \\
\hline & & Control & 112.42 & 119.12 & 14.54 & 14.69 & 10.78 & 10.86 & 0.268 & 0.265 \\
\hline Meal & for C & $100 \mathrm{mg} / \mathrm{L}$ & 124.23 & 126.67 & 15.17 & 15.21 & 10.65 & 10.66 & 0.316 & 0.315 \\
\hline & & $200 \mathrm{mg} / \mathrm{L}$ & 132.00 & 132.70 & 15.70 & 15.78 & 10.41 & 10.46 & 0.332 & 0.334 \\
\hline LSD & i A (Cattle & anure $\mathrm{m}^{3} / \mathrm{fed}$. & 15.95 & 17.30 & 0.66 & 0.75 & 0.4 & 0.51 & 0.047 & 0.045 \\
\hline & igation sc & dules regimes \%) & N.S. & N.S. & N.S. & N.S. & 0.13 & 0.15 & 0.021 & 0.025 \\
\hline LS D at $5 \%$ fo & C (Foliar applica & of of ascorbic acid) & \begin{tabular}{|l|l|}
8.21 \\
\end{tabular} & 8.98 & 0.33 & 0.41 & 0.27 & 0.21 & 0.036 & 0.041 \\
\hline $\mathrm{L}$ & $\%$ for Inte & tion $A^{*} B$ & 8.80 & 9.94 & \begin{tabular}{|l|l|} 
& 0.41 \\
\end{tabular} & 0.45 & 0.45 & 0.51 & 0.047 & 0.044 \\
\hline $\bar{L}$ & $\%$ for Inte & tion $A^{*} C$ & 8.54 & 9.67 & \begin{tabular}{|l|}
0.37 \\
\end{tabular} & 0.42 & 0.31 & 0.37 & 0.052 & 0.061 \\
\hline$\overline{8}$ & $\%$ for Inte & tion $\mathrm{B}^{*} \mathrm{C}$ & 8.54 & 9.67 & 0.37 & 0.42 & 0.31 & 0.37 & 0.052 & 0.061 \\
\hline LSD at & $\%$ for Interac & tion $A^{*} B^{*} C$ & 13.30 & 13.91 & 0.53 & 0.65 & 0.45 & 0.49 & 0.077 & 0.086 \\
\hline
\end{tabular}


Table (7): Effect of adding the cattle manure, irrigation schedule regimes, foliar application of ascorbic acid and their interactions on protein contents in pods, nitrogen, phosphorus and potassium content in leaves of snap bean plants during the two fall seasons of 2015 and 2016

\begin{tabular}{|c|c|c|c|c|c|c|c|c|c|c|}
\hline \multirow{2}{*}{$\begin{array}{l}\text { Cattle manure } \\
\text { amounts } \\
\left(\mathrm{m}^{3} / \mathrm{fed} .\right)\end{array}$} & \multirow{2}{*}{$\begin{array}{l}\text { Irrigation } \\
\text { schedule } \\
\text { regimes (\%) }\end{array}$} & \multirow{2}{*}{\begin{tabular}{|c|} 
Foliar \\
application \\
of ascorbic \\
acid (mg/L)
\end{tabular}} & \multicolumn{2}{|c|}{ Protein (\%) } & \multicolumn{2}{|c|}{ Nitrogen (\%) } & \multicolumn{2}{|c|}{ Phosphorus (\%) } & \multicolumn{2}{|c|}{ Potassium (\%) } \\
\hline & & & \begin{tabular}{c|}
$1^{\text {st }}$ \\
season
\end{tabular} & $\begin{array}{c}2^{\text {nd }} \\
\text { season }\end{array}$ & \begin{tabular}{c|}
$1^{\text {st }}$ \\
season
\end{tabular} & \begin{tabular}{|c|}
$2^{\text {nd }}$ \\
season
\end{tabular} & $\begin{array}{c}1^{\text {st }} \\
\text { season }\end{array}$ & $\begin{array}{c}2^{\text {nd }} \\
\text { season }\end{array}$ & $\begin{array}{c}1^{\text {st }} \\
\text { season }\end{array}$ & $\begin{array}{c}2^{\text {nd }} \\
\text { season }\end{array}$ \\
\hline \multirow{9}{*}{$20\left(\mathrm{~m}^{3} /\right.$ fed. $)$} & \multirow{3}{*}{$100 \%$} & Control & \begin{tabular}{|l|}
13.97 \\
\end{tabular} & 14.01 & 2.21 & 2.24 & 0.30 & 0.31 & 1.86 & 2.03 \\
\hline & & $100 \mathrm{mg} / \mathrm{L}$ & 14.92 & 15.01 & 2.40 & 2.38 & 0.32 & 0.31 & 2.08 & 2.13 \\
\hline & & $200 \mathrm{mg} / \mathrm{L}$ & 15.79 & 15.65 & 2.47 & 2.52 & 0.32 & 0.33 & 2.15 & 2.17 \\
\hline & \multirow{3}{*}{$80 \%$} & Control & \begin{tabular}{|l|}
13.76 \\
\end{tabular} & \begin{tabular}{|l|}
13.89 \\
\end{tabular} & 2.19 & 2.20 & 0.28 & 0.30 & 1.76 & 1.89 \\
\hline & & $100 \mathrm{mg} / \mathrm{L}$ & \begin{tabular}{|l|}
15.86 \\
\end{tabular} & 15.74 & 2.53 & 2.51 & 0.33 & 0.32 & 2.09 & 2.18 \\
\hline & & $200 \mathrm{mg} / \mathrm{L}$ & 15.99 & 16.34 & 2.55 & 2.58 & 0.33 & 0.34 & 2.18 & 2.24 \\
\hline & \multirow{3}{*}{$60 \%$} & Control & 13.72 & 13.74 & 2.17 & 2.19 & 0.28 & 0.29 & 1.69 & 1.84 \\
\hline & & $100 \mathrm{mg} / \mathrm{L}$ & 14.50 & 14.58 & 2.33 & 2.31 & 0.29 & 0.30 & 1.82 & 1.97 \\
\hline & & $200 \mathrm{mg} / \mathrm{L}$ & \begin{tabular}{|l|}
14.87 \\
\end{tabular} & 15.14 & 2.37 & 2.42 & 0.30 & 0.32 & 1.96 & 2.04 \\
\hline \multicolumn{3}{|c|}{ Mean for $\mathrm{A}$} & 14.82 & 14.90 & 2.36 & 2.37 & 0.31 & 0.31 & 1.95 & 2.05 \\
\hline \multirow{9}{*}{$30\left(\mathrm{~m}^{3} /\right.$ fed. $)$} & \multirow{3}{*}{$100 \%$} & Control & 16.53 & 16.73 & 2.66 & 2.64 & 0.34 & 0.35 & 2.19 & 2.24 \\
\hline & & $100 \mathrm{mg} / \mathrm{L}$ & \begin{tabular}{|l|}
17.22 \\
\end{tabular} & 17.10 & 2.72 & 2.75 & 0.34 & 0.36 & 2.22 & 2.28 \\
\hline & & $200 \mathrm{mg} / \mathrm{L}$ & 17.31 & 17.41 & 2.76 & 2.79 & 0.36 & 0.37 & 2.30 & 2.33 \\
\hline & \multirow{3}{*}{$80 \%$} & Control & 16.38 & 16.32 & 2.60 & 2.62 & 0.32 & 0.33 & 2.10 & 2.15 \\
\hline & & $100 \mathrm{mg} / \mathrm{L}$ & \begin{tabular}{|l|}
17.44 \\
\end{tabular} & 17.52 & 2.76 & 2.79 & 0.36 & 0.37 & 2.24 & 2.30 \\
\hline & & $200 \mathrm{mg} / \mathrm{L}$ & \begin{tabular}{|l|}
17.77 \\
\end{tabular} & 17.98 & 2.80 & 2.86 & 0.37 & 0.39 & 2.34 & 2.37 \\
\hline & \multirow{3}{*}{$60 \%$} & Control & 15.53 & 15.86 & 2.50 & 2.53 & 0.30 & 0.31 & 2.11 & 2.12 \\
\hline & & $100 \mathrm{mg} / \mathrm{L}$ & \begin{tabular}{|l|}
16.22 \\
\end{tabular} & 16.32 & 2.57 & 2.59 & 0.32 & 0.33 & 2.14 & 2.17 \\
\hline & & $200 \mathrm{mg} / \mathrm{L}$ & 16.75 & 16.99 & 2.68 & 2.71 & 0.34 & 0.35 & 2.18 & 2.25 \\
\hline \multicolumn{3}{|c|}{ Mea } & 16.79 & 16.91 & 2.67 & 2.70 & 0.34 & 0.35 & 2.20 & 2.25 \\
\hline \multirow{9}{*}{$40\left(\mathrm{~m}^{3} / \mathrm{fed}.\right)$} & \multirow{3}{*}{$100 \%$} & Control & \begin{tabular}{|l|}
14.32 \\
\end{tabular} & \begin{tabular}{|l|}
14.66 \\
\end{tabular} & 2.25 & 2.28 & 0.32 & 0.33 & 2.16 & 2.20 \\
\hline & & $100 \mathrm{mg} / \mathrm{L}$ & 15.40 & 15.44 & 2.46 & 2.43 & 0.32 & 0.33 & 2.19 & 2.25 \\
\hline & & $200 \mathrm{mg} / \mathrm{L}$ & \begin{tabular}{|l|}
16.01 \\
\end{tabular} & 16.15 & 2.55 & 2.58 & 0.33 & 0.34 & 2.28 & 2.31 \\
\hline & \multirow{3}{*}{$80 \%$} & Control & \begin{tabular}{|l|}
14.20 \\
\end{tabular} & 13.99 & 2.22 & 2.26 & 0.31 & 0.32 & 2.11 & 2.16 \\
\hline & & $100 \mathrm{mg} / \mathrm{L}$ & \begin{tabular}{|l|}
15.48 \\
\end{tabular} & 15.63 & 2.47 & 2.50 & 0.32 & 0.33 & 2.20 & 2.27 \\
\hline & & $200 \mathrm{mg} / \mathrm{L}$ & 16.66 & 16.85 & 2.62 & 2.69 & 0.36 & 0.37 & 2.29 & 2.33 \\
\hline & \multirow{3}{*}{$60 \%$} & Control & 13.61 & 13.85 & 2.19 & 2.23 & 0.29 & 0.30 & 2.07 & 2.10 \\
\hline & & $100 \mathrm{mg} / \mathrm{L}$ & 15.15 & 15.33 & 2.40 & 2.45 & 0.30 & 0.32 & 2.15 & 2.19 \\
\hline & & $200 \mathrm{mg} / \mathrm{L}$ & 15.06 & 15.70 & 2.45 & 2.56 & 0.32 & 0.34 & 2.18 & 2.22 \\
\hline & Mean for $\mathrm{A}$ & & 15.10 & 15.29 & 2.40 & 2.44 & 0.32 & 0.33 & 2.18 & 2.23 \\
\hline & & $100 \%$ & 15.69 & 15.77 & 2.49 & 2.50 & 0.32 & 0.33 & 2.16 & 2.21 \\
\hline Mea & or B & $80 \%$ & 15.96 & 16.11 & 2.53 & 2.57 & 0.33 & 0.34 & 2.15 & 2.21 \\
\hline & & $60 \%$ & \begin{tabular}{|l|}
15.05 \\
\end{tabular} & 15.28 & 2.41 & 2.44 & 0.30 & 0.31 & 2.03 & 2.10 \\
\hline & & Control & \begin{tabular}{|l|}
14.71 \\
\end{tabular} & 14.78 & 2.33 & 2.36 & 0.30 & 0.32 & 2.00 & 2.08 \\
\hline Mean & for $C$ & $100 \mathrm{mg} / \mathrm{L}$ & \begin{tabular}{|l|}
15.80 \\
\end{tabular} & 15.63 & 2.56 & 2.52 & 0.32 & 0.33 & 2.13 & 2.19 \\
\hline & & $200 \mathrm{mg} / \mathrm{L}$ & 16.25 & 16.36 & 2.58 & 2.64 & 0.34 & 0.35 & 2.21 & 2.25 \\
\hline LS S at $5 \%$ fo & r A (Cattle ma & nure $\mathrm{m}^{3} / \mathrm{fed}$.) & 0.41 & 0.51 & 0.064 & 0.083 & 0.036 & 0.052 & 0.027 & \begin{tabular}{|l|}
0.031 \\
\end{tabular} \\
\hline LSD at $5 \%$ for $\mathrm{E}$ & (Irrigation schec & dule regimes $\%)$ & 0.25 & 0.29 & 0.038 & 0.044 & N.S. & N.S. & N.S. & N.S. \\
\hline $\begin{array}{r}\text { LSD at } 5 \% \\
\text { of } \\
\end{array}$ & $\begin{array}{l}\text { for C (Foliar } \\
\text { ascorbic acid }\end{array}$ & application & 0.19 & 0.28 & 0.040 & 0.064 & 0.023 & 0.027 & 0.19 & N.S. \\
\hline LSD at 5 & $\%$ for interac & ction $A^{*} B$ & 0.33 & 0.34 & 0.050 & 0.059 & 0.024 & 0.039 & N. S. & N. S. \\
\hline LS D at 5 & $\%$ for interac & ction $A^{*} C$ & 0.21 & 0.31 & 0.040 & 0.072 & 0.026 & N. S. & N. S. & N. S. \\
\hline LS D at 5 & $\%$ for interac & ction $B^{*} C$ & 0.21 & 0.31 & 0.040 & 0.072 & 0.026 & N. S. & 0.059 & 0.051 \\
\hline LSD at $5^{\circ}$ & o tor mineract & IOII A D C & 0.30 & 0.45 & 0.090 & 0.124 & 0.037 & 0.043 & 0.084 & 0.073 \\
\hline
\end{tabular}




\section{3-2-Effect of water regimes:}

Regarding to the results of the previous chemical composition of snap bean leaves and pods presented in Tables (6 and 7) showed that, the highly significant values occurred in pods when snap bean plants received the complete irrigation treatment (100\% from plant irrigation requirements /fed.). On contrast, increasing water deficient from $80 \%$ to $60 \% /$ fed. significantly increased the fiber contents \% in pods. The highest amount of proline content \% achieved in snap bean leaves when irrigated the plants with the middle water regime treatment followed with $100 \% /$ fed. but under the highest severe of water stress $(60 \% /$ fed.) proline tended to decrease. These results coincided with those reported by Shenkut and Brick (2003) they decided that the lowest fiber content was observed in snap bean plants received $100 \%$ water level in the two seasons. They also, suggested that low irrigation level or drought stress caused a reduction in plant size which due to a decrease in extension growth and increased leaf thickness. Nakayama et al. (2007) concluded that severe drought accelerated leaf senescence by reducing leaf nitrogen concentration producing a decrease in photosynthesis rate on soybean plants. The accumulation of proline and amino acids in the cytoplasm plays an important role in the osmotic balance of plants and are good indicators of tolerance. Naresh et al. (2013) found that the increase of free proline occurs under decrease of water supply in mung bean plants extensively protects cell membrane and protein content in plant leaves suggests an excellent mechanism to mitigate the injurious effect of water stress. Amira (2014) reported that the most decrease in the concentration of photosynthetic pigments i.e. total chlorophyll, as a result of drought stress reduced the uptake of nitrogen, phosphorus and potassium content $\%$ under the condition of $40 \%$ (field capacity) of soybean plants. The proline concentration was increased under the middle drought stress only because of proline is a key in osmosis regulation. Increasing the amount of proline and sugars in the plants would lead to the resistance against loose water, protect turgor, reduce the membrane damage and accelerate the growth of Satureja hortensis plants under stress conditions (Yazdanpanah et al., 2011). Neama et al. (2016) generalized that subjected the snap bean plants to three water levels $(100,80$, and $60 \%$ of the potential evapotranspiration) led to significant increase in pod quality i.e. protein, chlorophyll content and fibers content at full irrigation (100\%) treatment. It was found that the reduction of the previous characters occurred under decreasing water regimes from $80 \%$ to $60 \% /$ fed., gave the highest reduction in pod quality pronounces in the level of $60 \% / \mathrm{fed}$.

\section{3-3-Effect of foliar spraying with ascorbic acid:}

Respecting to the effect of spraying bean plants with ascorbic acid treatments under this investigation on chemical composition of leaves and pods quality, the results presented in the Tables 6 and 7 show that, foliar spraying with the aqueous solution of ascorbic acid lead to significant increases of all chemical composition in the leaves and the pods especially, decreasing the fiber contents \% in the pods when ascorbic acid was sprayed at the highest rate of $200 \mathrm{mg} / \mathrm{L}$ as compared with the moderate or the control one. These results are come to the same conclusion by Gallie (2012) who, suggested that, one of the main roles of ascorbic acid is to maintain a cation-anion balance in the plant tissues by stabilizing cell membranes at high external abiotic stress. In this concern, ascorbic acid can mitigate the adverse effects of drought through increasing the content of IAA and $\mathrm{GA}_{3}$ and decreasing $A B A$ level, which may be involved in protecting the photosynthetic apparatus and consequently increasing the photosynthetic pigments in common bean plants (Saeidi-Sar et al., 2013). Hosny et al. 
(2015) demonstrated that spraying snap bean plants with ascorbic acid at $400 \mathrm{mg} / \mathrm{L}$ increased chlorophyll a, b, carotenoids, nitrogen, phosphorus, potassium and crude protein in the pods compared with the control.

\section{3-4-Effect of the interactions:}

The data in Tables (6 and 7) indicate that there were significant interactions among the all the treatments, the results show that the superiority combined treatment was added the cattle manure at the amount of 30 $\mathrm{m}^{3} /$ fed., irrigated plants with $80 \%$ from plants irrigation requirements $/ \mathrm{fed}$. and sprayed ascorbic acid at $200(\mathrm{mg} / \mathrm{L})$ which increased the total chlorophyll, proline, nitrogen, phosphorus and potassium contents in the leaves as well as able to rise the snap bean pods quality with increasing the carbohydrates and protein as well as decreasing the fibers content in the pods. On the contrary, the worst characters on chemical compositions and the highest value of the fibers content $\%$ in pods were obtained with adding the cattle manure at 20 $\mathrm{m}^{3} /$ fed., irrigated water at rate of $60 \% /$ fed. as well as spraying ascorbic acid with 100 (mg/ L) as compared with the two other interactions. Non-significant increases obtained with water regimes in the total chlorophyll, carbohydrates, phosphorus and potassium content in the two seasons, spraying ascorbic acid on potassium content $\%$ in the $2^{\text {nd }}$ season only, on phosphorus contents \% with interactions of cattle manure with spraying ascorbic acid, irrigation water regimes with spraying ascorbic acid in the $2^{\text {nd }}$ season only, on potassium content $\%$ in the interactions of cattle manure with irrigation water regimes and cattle manure with spraying ascorbic acid in the two seasons, respectively. These conclusions are confirmed with the results of mentioned by Khan et al. (2011) they, stated that the positive effects of ascorbic acid in the counteraction of the adverse effects of water stress are the stabilization and protection of the photosynthetic pigments and the photosynthetic apparatus from oxidization. Moreover, ascorbic acid stimulated proline accumulation under the condition of water stressed plants. Increasing the amount of proline and sugars in the plants would lead to the resistance against loose water, protect turgor, reduce the membrane damage and accelerate the growth of plants under stress conditions (Gallie, 2012). Reza et al. (2013) proved that the interaction between water regime and application of 30 ton/ ha. cattle manure induced significant effect to produce the highest total chlorophyll content of soybean plants. Saeidi-Sar et al. (2013) found that exogenous supply of ascorbic acid enhanced potassium concentration under the condition of water- stressed in common bean plants. These increases were attributed to the positive effect of ascorbic acid on the root growth, which consequently increased the absorption of different nutrients and alleviated the harmful effects of water stress. Also, its increasing nutrient uptake, elements content such as nitrogen, phosphorous and potassium. Hosny et al. (2015) concluded that significant increases were obtained on the concentrations of chlorophyll a, b, nitrogen, phosphorus, potassium and crude protein in green pods as a result of the interaction between irrigation snap bean plants under water regime levels of 50 and $35 \%$ of pan evapotranspiration and spraying with the highest concentration of ascorbic acid at the dose of $400 \mathrm{mg} / \mathrm{L}$.

\section{The recommendations}

Finally, it could be concluded that, under the conditions of this investigation it can recommended by cultivate, snap bean plants Bronco cv. for local or export marketing with adding the cattle manure at rate of $30 \mathrm{~m}^{3} /$ fed., irrigation with the appropriate schedule water regime at $80 \%$ from plants irrigation requirements/ fed. as well as application of ascorbic acid with 200 (mg/ L) as foliar spray to obtain superior effects in the vegetative growth character, 
marketable, total yield (ton/ fed.) and its components, water use efficiency and best pod quality as well as it is very important for saving a part of the irrigation water (about $20 \%$ ) especially under the condition of the limited water resources nowadays for the newly reclaimed areas in Egypt.

\section{REFERENCES}

Abdul-Jaleel, C., P. Manivannan, A. Wahid, M. Farooq, $H$. J. Al-Juburi, R. Somasundaram and R. Panneerselvam (2009). Drought stress in plants: A Review on morphological characteristics and pigments composition. Int. J. Agric. Biol. 11: 100-105.

Abiven, S., S. Menasseri and C. Chenu (2008). The effects of organic inputs over time on soil aggregate stability. Elsevier., soil biology and biochemistry. 41:1 - 12 .

Abu-Zeid, M. and A. Hamdy (2002). Water vision for the twenty-first century in the Arab world. $3^{\text {rd }}$ world water forum.

Allahyari, M. S., M. Chizari and M. Homaee (2008). Perceptions of Iranian agricultural extension professionals toward sustainable agriculture concepts. J. Agric. Soc., Sci. 4(3):101-106.

Amer, H. A., A. Fathey and Y. S. Khfaga (2012). Snap bean cultivation and production. Hort. Res. Inst., Agric., Res. Center. Ministry of Agric. Bull. No. 1281.

Amira, M. S. A. (2014). Effect of ascorbic acid antioxidant soybean (Glycine max L.) plants grown under water stress conditions. Int. J. Adv. Res. Biol., Sci. 1(6):189-205.

Arjumand, B. S. S., N. B. Ananth and E. T. Puttaiah (2013). Effectiveness of farmyard manure. poultry manure and fertilizer - NPK on the growth parameters of French bean (Phaseolus vulgaris $\mathrm{L}$ ). J. Current Res. 1(1):31-35.

Bakayoko, S., D. Soro and K. K. H. Kouadio (2013). Cattle manure effects on structural stability and water retention capacity of a sandy soil in Côte D'ivoire. Ind. J. Sci. Res. and Tech. (2):48-52.
Benke, M. B., S. P. Indraratne, X. Hao, C. Chang and T. B. Goh (2008). Trace element changes in soil after long-term cattle manure applications. J. Environ., Qual. 37:798 - 807.

Bhaskarrao, C., T. D. Dagne, D. S. Vijaya and L. B. Melaku (2015). A comparative study on the effect of organic and inorganic fertilizers on agronomic performance of faba bean (Vicia faba L.) and pea (Pisum sativum L.). Agric., forestry and fisheries. 4(6): 263-268.

Bricker, B. (1991). MSTATC: A micro computer program from the design management and analysis of agronomic research experiments. Michigan State Univ. USA.

Brown, J. G. and P. K. Jackson (1955). Anate on the potentiometric determination of chloride. Proc. Amer. Soc. Hort., Sci. 65:187-194.

Chaudhury, R. S. (2014). Advances in nutrient dynamics in soil - plant atmosphere system for improving nutrient use efficiency. Indian Inst., Soil Sci. Pages: 46-47.

Conklin, P. L. (2001). Recent advances in the role and biosynthesis of ascorbic acid in plants. Plant, Cell and Environ. 24: 383-394.

Dubois, M., K. M. Gilles, J. K. Hamilton, P. A. Robers and F. Smith (1975). Calorimetric method for determination of sugars and related substances. Anolyt. Chem. 28:350.

El-Noemani, A. A., H. A. El-Zeiny, A. M. ElGindy, E. A. El-Sahhar and M. A. ElShawadfy (2010). Performance of some bean (Phaseolus vulgaris L.) varieties under different irrigation systems and regimes. Australian J. Basic and Applied Sci. 4(12): 6185-6196.

El-Shiekh, M. H., M. H. Ibrahim, A. Y. Ragab and A. M. Ibrahim (2016). Effect of some antioxidants on water use efficiency, growth and yield of faba bean cultivar in newly reclaimed soil. Middle East J. Agric. Vol.: 05 - Issue: 03. July-Sept. Pages: 279-285. 
El-Tohamy, W. A., H. M. El-Abagy, M. A. Badr and N. Gruda (2013). Drought tolerance and water status of bean plants (Phaseolus vulgaris L.) as affected by citric acid application. J. Applied Botany and Food Quality. 86, 212 - 216.

Gallie, D. R. (2012). The role of I-ascorbic acid recycling in responding to environmental stress and in promoting plant growth. J. Exper. Bot. 16, 1-11.

Hosny, M. M. A., A. M. M. Mohamed, M. M. A. Mohamed and S. M. E. Rania (2015). Effect of some antioxidants, potassium and arbuscular mycorrhiza on growth, yield and quality of snap bean plants grown under water stress levels. Annals of Agric. Sci., Moshtohor. Vol. 53(1) 1530.

Jackson, M. L. (1973). Soil Chemical Analysis. Prentic-Hall, Indian.

Karangwa, A. N. F., B. Charles, M. Edouard and H. Sylvestre (2015). Effect test of industrial organic manure on the physical growth and yield performance of bean in Bugesera district environment. East African J. Sci., Tech. Vol. 5 issue 2.

Kelly, J. D. and F. A. Bliss (1975). Heritability estimates of percentage seed protein and available methionine and correlations with yield in dry bean. Crop Sci. 15: 753-757.

Khan, T. A., M. Mazid and F. Mohammad (2011). A review of ascorbic acid potentialities against oxidative stress induced in plants. J. Agrobiol. 28(2):97111.

King, E. J. (1951). Micro-Analysis in Medical Biochemistry. $2^{\text {nd }}$ Ed., Churchil, Landon.

Kovacs, A. B., I. Vago and R. Kremper (2008). Growth and yield responses of garden bean (Phaseolus vulgaris L) to nitrogen and sulfur fertilization. Analele Univ. din Oradea, Fascicula: Protectia Mediului. Vol. 13 No 4. Pages: 93-111.

Lal, R. (2008). Managing soil water to improve rained agriculture in India. $\mathrm{J}$. Sustainable Agric. 32: 51-75.

Liu, F. L., M. N. Andersen and C. R. Jensen (2003). Loss of pod set caused by drought stress is associated with water status and ABA content of reproductive structures in soybean. Functional Plant Biology. 30: 271-280.

Lunazendejas, H. S., M. Solis, W. Lopez, A. R. Vera and J. M. P. Gonzalez-Prieto (2011). Effect of compost made with sludge and organic residues on bean (Phaseolus vulgaris L.) crop and arbuscular myccorrhizal fungi density. African J. Agric., Res. 6 (6): 1580- 1585.

Nagata, M. and I. Yamashita (1992). Simple method for simultaneous determination of chlorophyll and carotenoids in tomato fruit. J. Japan Soc. Food Sci. Technol. 39: 928-932.

Nakayama, N., H. Saneoka, R. E. A. Moghaieb, G. S. Premachandra and K. Fujita (2007). Response of growth, photosynthetic gas exchange, translocation of $\mathrm{C}^{13}$ labeled photosynthetic and $\mathrm{N}$ accumulation in two soybean (Glycine max L.) cultivars to drought stress. Int. J. Agric. Biol. 9: 669674.

Naresh, R. K., S. P. S. Purushottam, D. Ashish and K. Vineet (2013). Effects of water stress on physiological processes and yield attributes of different mung bean (L.) varieties. African J. Biochemistry Res. Vol. 7(5), Pages: 5562.

Neama, M. M., R. E. Abdelraouf, S. R. Salman and M. M. H. Abd-El Baky (2016). Effect of water stress on yield and quality traits of different snap bean varieties grown in an arid environment. Middle East J. Agric. Vol.: 05, Issue: 04. Oct.-Dec. Pages: 629-635.

Pregl, F. (1945). Quantitative Organic Micro Analysis. $4^{\text {th }}$, Ed. J. and Churchill Ltd. London.

Rahil, M. H. and A. Qanadillo (2015). Effects of different irrigation regimes on yield and water use efficiency of cucumber crop. Agric., Water Manag. 148, $10-15$.

Rai, S. N. and V. D. Mudgal (1988). Synergistic effect of sodium hydroxide and steam pressure treatment on 
compositional changes and fiber utilization of wheat straw. Biological waster. 4: $105-114$.

Razinger, J., L. Drinovec, J. Sustar-vozlic, B. Cremopnik, V. Meglic and A. Cerenak (2010). Physiological response of common bean (Phaseolus vulgaris L.) to drought stress. Hmeljarski bilten / Hop Bull. 17: 44-56.

Reyndres, I. and K. Vlassak (1982). Use of Asospirillum brasilense as biofertilizer in intensive wheat cropping. Plant and soil. 66: $217-223$

Reza, N., R. Hamid, M. Tohidi and Z. Hossein (2013). Effect of cattle manure and zeolite applications on physiological and biochemical changes in soybean [Glycine max (L.) Merr.] grown under water deficit stress. Revista Científica UDO 76 Agrícola. 13 (1): 76-84.

Rocha-Guzman, N. E. and J. A. GallegosInfante (2007). Antioxidant activity in Cotyledon of Black and Yellow Common beans (Phaseolus Vulgaris L). Res. J. Biol. Sci.: 2 (1): 112-117.

Saeidi-Sar, S., H. Abbaspour, H. Afshari and S. R. Yaghoobi (2013). Effects of ascorbic acid and gibberellin $\mathrm{GA}_{3}$ on alleviation of salt stress in common bean (Phaseolus vulgaris L.) seedlings. Acta. Physiol., Plant. 35: 667-677.
Sánchez-Rodríguez, E., R. M. M. Delmar, B. Blasco and L. Rocío (2012). Antioxidant response resides in the shoot in reciprocal grafts of drought-tolerant and drought-sensitive cultivars in tomato under water stress. Plant Sci. V. 188189. No. 1: 89-96.

Shenkut, A. A. and M. A. Brick (2003). Traits associated with dry edible bean (Phaseolus vulgaris L.) associated with dry edible bean productivity under diverse soil moisture environments. Euphytica. 133: 339-347.

Smirnof, N. and G. L. Wheeler (2000). Ascorbic acid in plants. Biosynthesis and Function. Current Review in Plant Sci. 19: 267-290.

Thomas, A. J. R. (1967). The rule of the ring. J. Cell. Physiol. 70: (Suppl. 1) 1334.

Troll, W. and J. Lindsley (1955). A photometric method for determination of proline. J. Biol., Chem. 215: 655-660.

Yazdanpanah, S., A. Baghizadeh and F. Abbassi (2011). The interaction between drought stress, salicylic and ascorbic acids on some biochemical characteristics of Satureja hortensis. African J. Agric., Res. 6(4): 798-807. 


\title{
إستجابة نمو وانتاجية نباتات الفاصوليا للتسميد العضوى ومقتنات الرى والرش بحامض الرض الاسكوريك تحت ظروف الأراضى حليثة الأستصلاح
}

\author{
ربيع حسن محمد غيث ، مدحت أحمد عبد العزيز \\ قنسم بحوث الخضر ذاتية التلقيح، معهد بحوث البساتين- مركز البحوث الزراعية- الجيزة- مصر ملئر
}

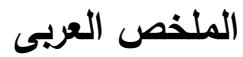

أجريت تجربتان حقليتان بمزرعة خاصة بمنطقة بنى مزار شمال محافظة المنيا فى الموسم النيلى لعامى 2015 - 2016

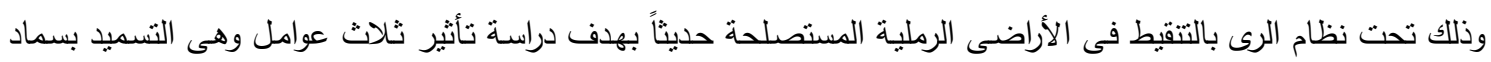

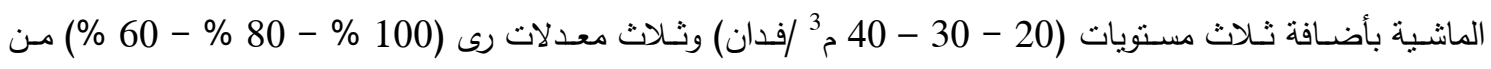

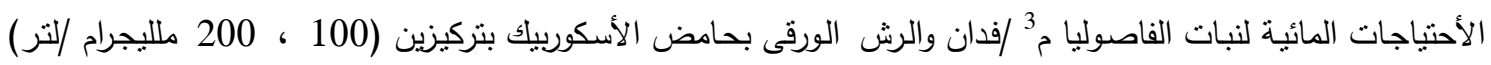

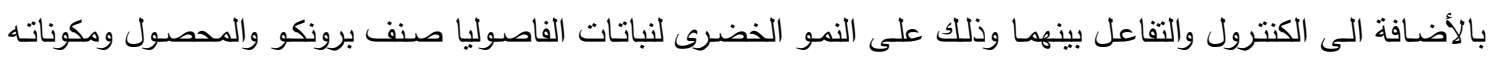

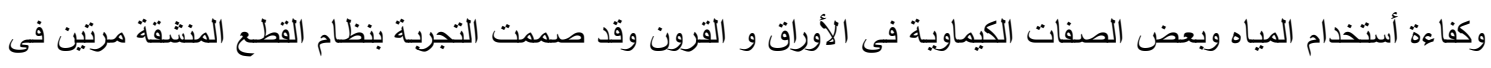

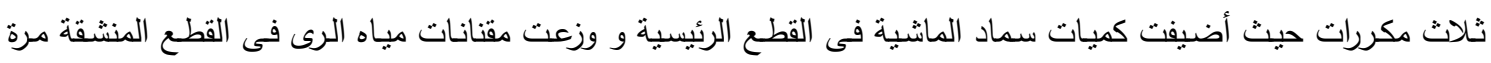
واحدة بينما الرش الورقى بحامض الأسكوربك وضع فى القطع المنشقة مرتين وتم زراعة بذور الفاصوليا فى الأسبوع الثانى

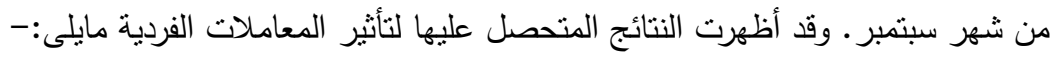

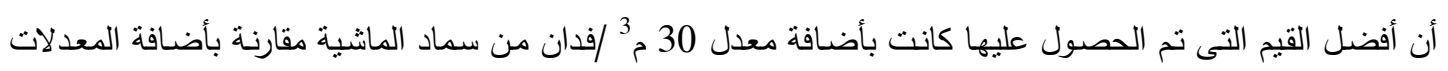

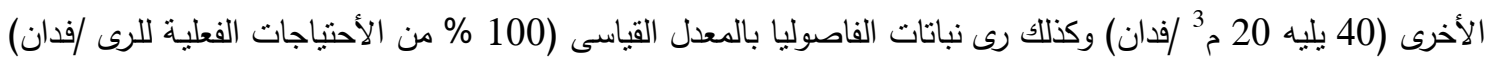

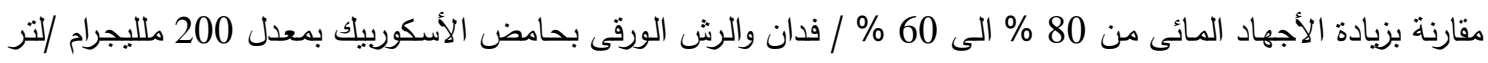

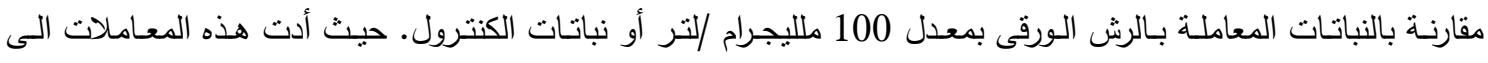

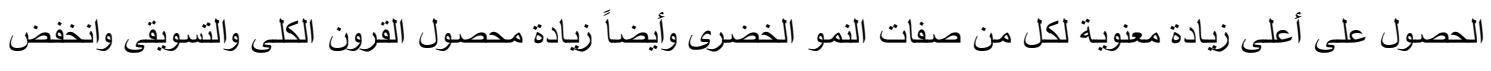

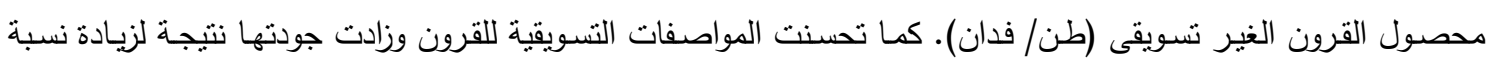
الكربوهيدرات والبروتين (\%) كذلك زادت نسبة كل من الكلوروفيل (ملليجرام /100 جرام وزن طازج) والنتروجين والفوسفور

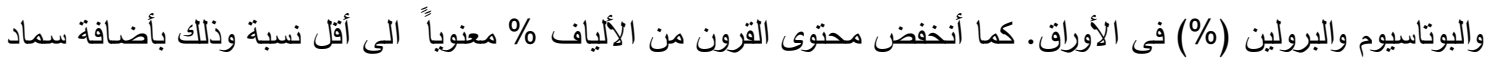

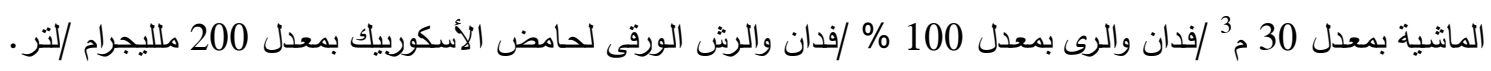

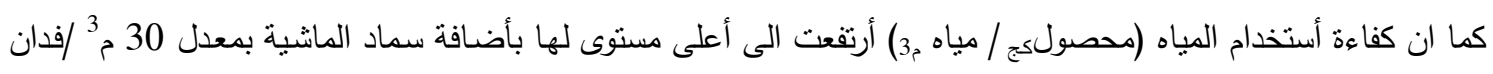

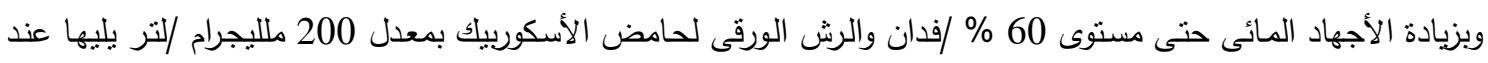

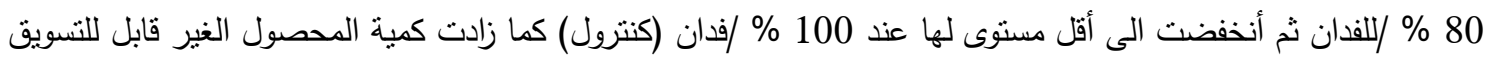

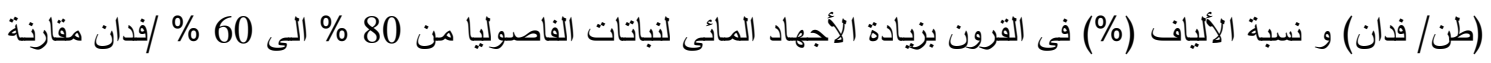

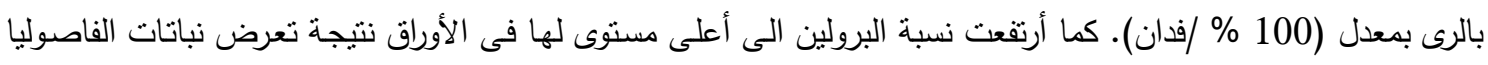

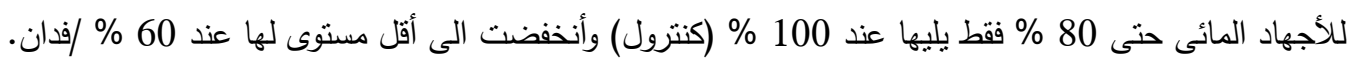

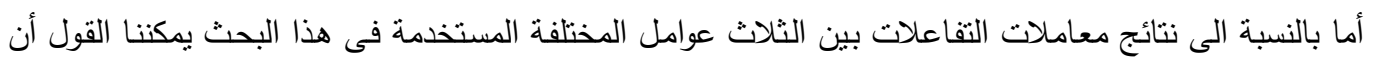
هذه المعاملات أدت الى زيادة معنوية فى معظم الصفات المدروسة وخاصة معاملة التفاعل بين أضافة سماد المانشية بمعدل

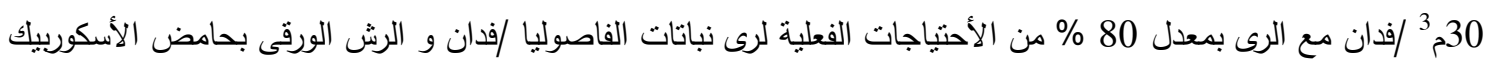


بتركيز 200 ملليجرام /لثز ويعتبر هذا التفاعل أفضل المعاملات حيث أعطى أعلا النتائج المتحصل عليها تحت ظروف هذا

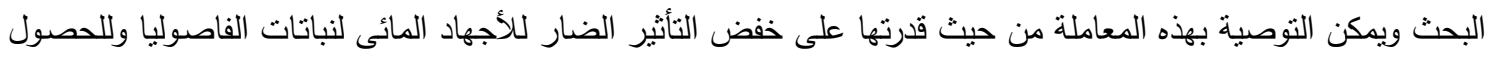

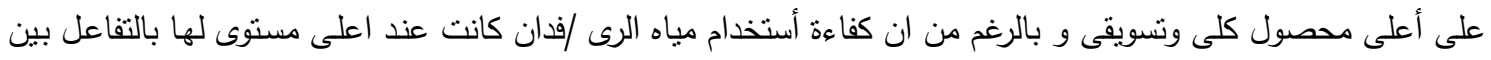

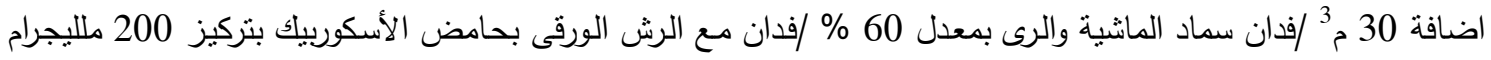
/لتر ولكن التفاعل السابق يعتبر هو الأفضل للحصول على أعلى زيادة معنوية مدكنة من المحصول الكعلى والثى والتسويقى وأقل

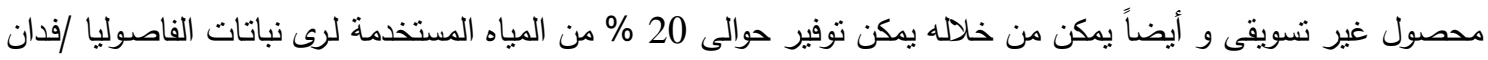

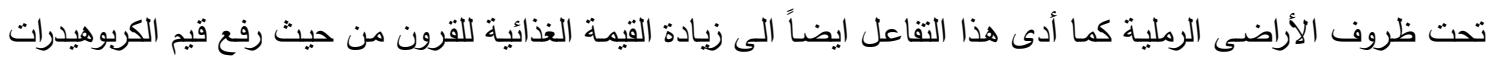

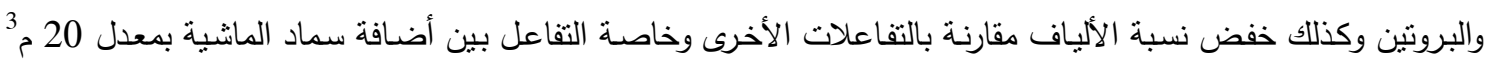

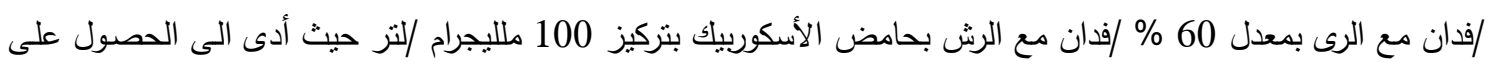
أقل القيم تحت الدراسة وذللك فى كلا الموسمين على التوالى.

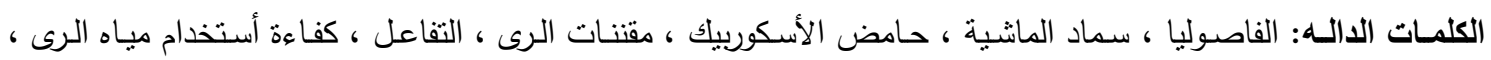
الأراضى المسنصلحة حديثاً 